\title{
Identification of Xylella fastidiosa Antivirulence Genes: Hemagglutinin Adhesins Contribute to $X$. fastidiosa Biofilm Maturation and Colonization and Attenuate Virulence
}

\author{
Magalie R. Guilhabert and Bruce C. Kirkpatrick \\ Department of Plant Pathology, University of California, Davis 95616, U.S.A. \\ Submitted 2 February 2005. Accepted 15 April 2005.
}

\begin{abstract}
Xylella fastidosa, a gram-negative, xylem-limited bacterium, is the causal agent of several economically important plant diseases, including Pierce's disease (PD) and citrus variegated chlorosis (CVC). Until recently, the inability to transform or produce transposon mutants of $X$. fastidos $a$ had been a major impediment to identifying $X$. fastidosa genes that mediate pathogen and plant interactions. A random transposon (Tn5) library of $X$. fastidosa was constructed and screened for mutants showing more severe symptoms and earlier grapevine death (hypervirulence) than did vines infected with the wild type. Seven hypervirulent mutants identified in this screen moved faster and reached higher populations than the wild type in grapevines. These results suggest that $X$. fastidosa attenuates its virulence in planta and that movement is important in $X$. fastidosa virulence. The mutated genes were sequenced and none had been described previously as antivirulence genes, although six of them showed similarity with genes of known functions in other organisms. One transposon insertion inactivated a hemagglutinin adhesin gene (PD2118), which we named HxfA. Another mutant in a second putative $X$. fastidosa hemagglutinin gene, PD1792 (HxfB), was constructed, and further characterization of these $h x f$ mutants suggests that $X$. fastidosa hemagglutinins mediate contact between $X$. fastidosa cells, which results in colony formation and biofilm maturation within the xylem vessels.
\end{abstract}

Additional keywords: TpsA, TpsB, two-partner secretion pathway.

Xylella fastidiosa is a gram-negative, xylem-limited bacterium that is phylogenetically most closely related to Xanthomonas spp. X. fastidosa is transmitted from plant to plant by several xylem-feeding insect vectors (Hopkins 1989), and strains of $X$. fastidosa cause diseases in many economically important plants, including grapevines, citrus, peach, plum, oleander, elm, sycamore, oak, maple, and coffee (De Lima et al. 1998; Purcell 1997). The major symptoms of most X. fastidosa diseases are associated with water stress, due to reduced xylem flow, which is thought to result from occlusion of the xylem vessels by bacterial aggregates that likely contains extracellular polysaccharides (EPS) (da Silva et al. 2001), gums,

Corresponding author: B. C. Kirkpatrick; Telephone: (530) 752-2831; Fax: 752-5674; E-mail: bckirkpatrick@ucdavis.edu and tyloses (Hopkins 1989). Disease progression in Pierce's disease (PD) is characterized by leaf margins that progressively dry inward and scorched leaf blades abscise and fall, leaving the petiole attached to the cane (matchstick symptom). The canes lignify irregularly, which produces patches of green tissues surrounded by mature, brown tissue (green island symptom). Fruit desiccates and is economically worthless. Vine cordons die back and eventually all infected Vitis vinifera grapevines die.

Understanding the complex interactions among the pathogen, plant, and insect vector is imperative for the development of effective disease controls. However, very little is known about the basis of host specificity and the mechanisms by which $X$. fastidosa causes plant disease symptoms (Purcell and Hopkins 1996). The complete genome sequences of a citrus strain causing citrus variegated chlorosis (CVC) and a grapevine strain causing PD (X. fastidosa Temecula isolate) have been determined (Simpson et al. 2000; Van Sluys et al. 2003). Additionally, draft sequences of the almond- and oleander-infecting $X$. fastidosa strains also are available through the Joint Genomics Institute (JGI) of the United States Department of Energy (Bhattacharyya et al. 2002). Approximately $40 \%$ of the identified open reading frames (ORFs) in the various $X$. fastidosa strains encode proteins with no assignable function, whereas other designations, based solely on sequence homology, may not be correct (Bhattacharyya et al. 2002; Simpson et al. 2000; Van Sluys et al. 2003). Comparisons between the $X$. fastidosa PD and CVC strains showed that the PD Temecula strain has 41 strain-specific genes (1.9\% of the genome), whereas the CVC strain has 152 such genes (6.8\% of the genome) (Van Sluys et al. 2003). Those strain-specific genes may have evolved to facilitate differences in X. fastidosa pathogenicity.

The inability to transform or produce transposon mutants of $X$. fastidosa had been a major impediment to understanding the pathogen and its plant and insect-vector interactions. However, we developed a transposome-mediated mutagenesis system (Guilhabert et al. 2001) and constructed a random transposon (Tn5) library of $X$. fastidosa (this study). We demonstrated how screening of $X$. fastidosa random mutants in grapevines can identify $X$. fastidosa pathogenicity, movement, and regulatory genes that are important in the disease process. Here, we report the identification and characterization of seven $X$. fastidosa mutants that showed hypervirulence; mutants that produced more severe and earlier disease onset than the parental strain when they were inoculated into several $V$. vinifera cultivars. These results validate our strategy of using a random mutagenesis 
approach to unbiasedly screen the entire $X$. fastidiosa genome for pathogenesis-related genes.

One of the hypervirulent mutations occurred in a hemagglutinin adhesin (PD2118), which we named HxfA ( $\mathrm{H}$ for hemagglutinin, $\mathrm{xf}$ for $X$. fastidiosa, A for the first hemagglutinin described in $X$. fastidosa). We also constructed another mutant in a second putative $X$. fastidosa hemagglutinin gene, PD1792, which we named HxfB. We propose that HxfA and HxfB are secreted through a two-partner secretion pathway (TPS) with $X$. fastidosa PD1933 gene product being the cognate secretion partner, TpsB. We show that bacterial hemagglutinins, which are involved in several animal and plant diseases (Locht et al. 2001; Rojas et al. 2002), also are involved in the virulence of $X$. fastidosa in grapevines. Further characterization of the $h x f \mathrm{~A}$ and $h x f \mathrm{~B}$ mutants revealed that their cell-to-cell aggregation and biofilm maturation was altered in vitro and in planta. The correlation between hypervirulence and movement demonstrates the importance of movement in $X$. fastidosa pathogenicity, and the identification of novel "attenuation" genes provides insight into how $X$. fastidosa modulates its parasitism and pathogenicity.

\section{RESULTS}

Pathogenicity assays and identification of $X$. fastidosa hypervirulent mutants.

In order to understand the mechanisms by which $X$. fastidosa causes plant disease, we took a random transposition approach to disrupt genes potentially involved in $X$. fastidosa virulence or movement in grapevine plants. One thousand random $X$. fastidosa mutants were inoculated individually in grapevines and the symptoms were rated on a visual scale from 0 to 5 (Fig. 1; discussed below). Seven putative hypervirulent $X$. fastidosa mutants (i.e., grapevines inoculated with these Tn 5 mutants developed more severe disease symptoms than did vines inoculated with the wild-type Temecula strain 21 weeks after inoculation) were selected and retested by inoculating three additional Chardonnay (Fig. 2) as well as three Chenin Blanc and Thompson seedless grapevines (data not shown). All 7 Tn5 X. fastidosa hypervirulent mutants showed i) earlier symptom development, ii) higher disease scores over a period of 32 weeks, and iii) earlier vine death of all three grapevine cultivars compared with vines inoculated with the wild-type $X$. fastidos $a$ strain.
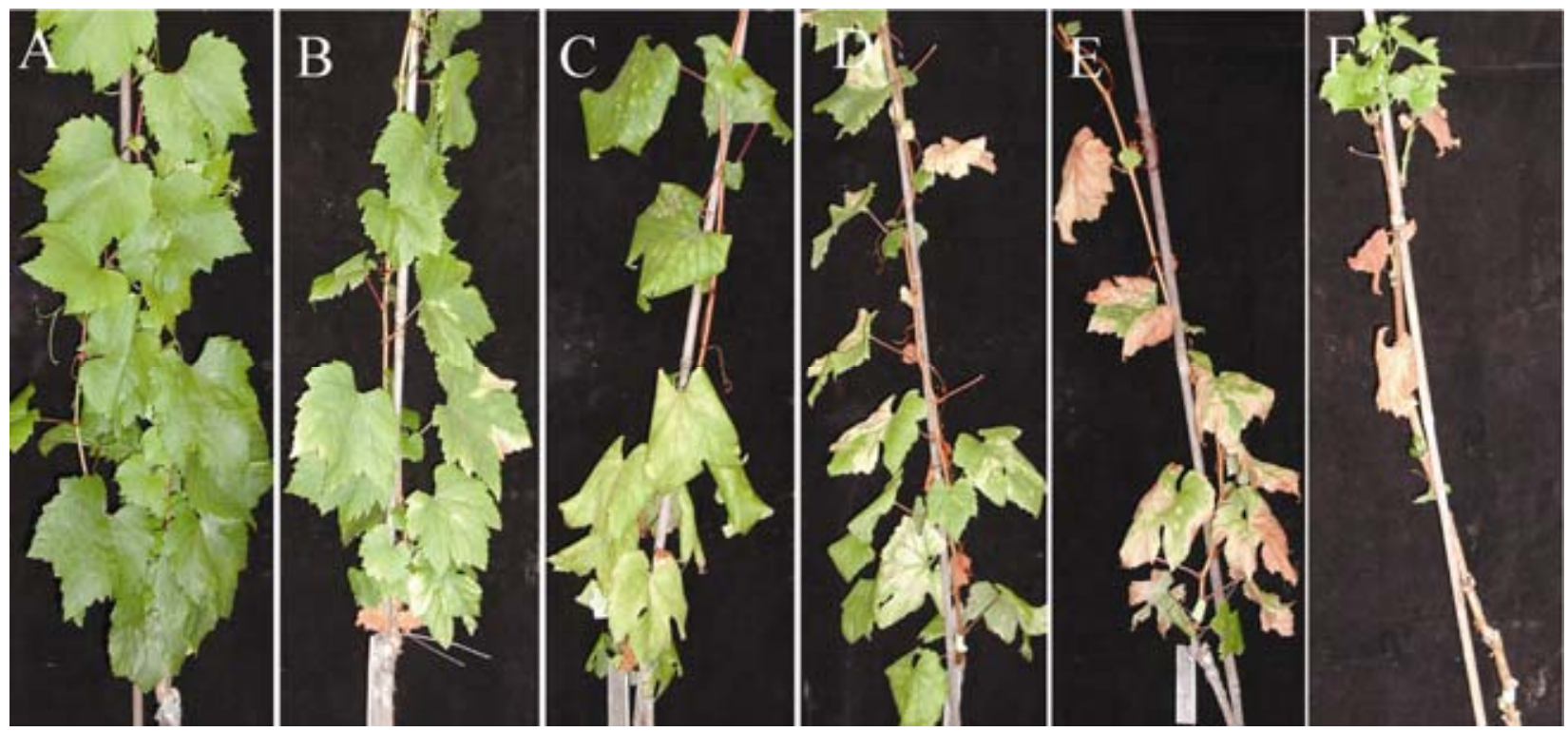

Fig. 1. Pierce's disease symptoms in grapevines. A, Mock inoculation of Chardonnay grapevines and $\mathbf{B}$ through $\mathbf{F}$, Chardonnay grapevines infected with the wildtype strain Temecula, showing a disease rating of $1,2,3,4$, and 5 , respectively. Note the general health of the plants and the number of scorched leaves.

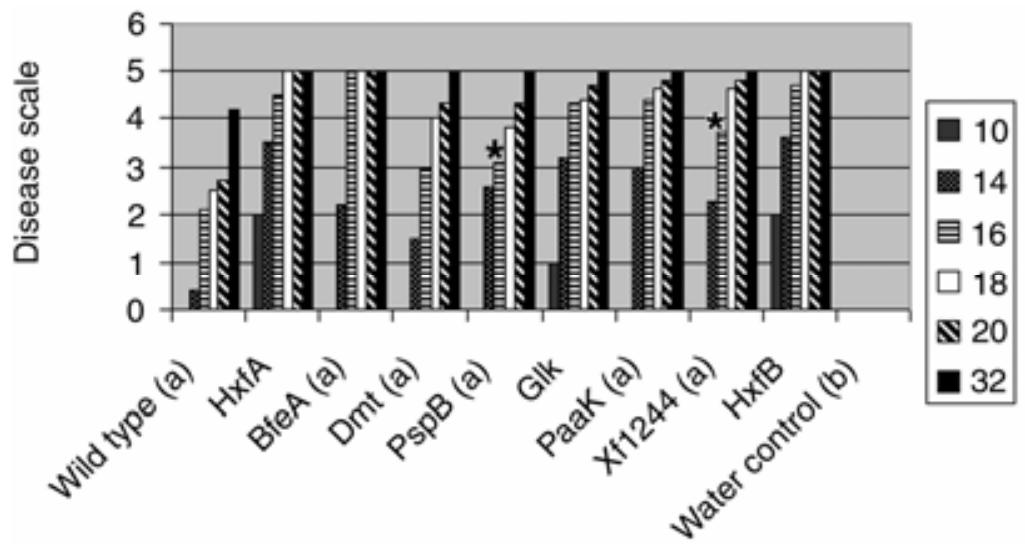

Fig. 2. Disease progression of Chardonnay grapevines inoculated with wild-type Xylella fastidiosa, Temecula strain, or Tn5 mutants of X. fastidiosa. Disease severity was based on a visual disease scale of 0 to 5 and was assessed 10,14, 16, 18, 20, and 32 weeks after inoculation. The data is an average of two independent replications (six plants total). (a) = Disease severity was rated as 0 (healthy) 10 weeks after inoculation. $(b)=$ Water control did not show any symptoms during 32 weeks, thus the rating was $0 .{ }^{*}=$ Mutant values were not significantly different from wild-type values at the $95 \%$ confidence level $(P<$ $0.05)$ at these time periods. 
Identification of genes associated

with the hypervirulent phenotype and

lipopolysaccharide gel analysis.

In order to determine the identity of the mutated genes, the transposon insertion sites of the mutants were identified using a combination of polymerase chain reaction (PCR) and sequencing (Table 1). Six of the mutated genes corresponded to genes with assignable functions and one gave a significant match with a hypothetical conserved gene. Southern blot analysis of the hypervirulent $X$. fastidosa mutants showed that the clones contained a single transposon insertion (data not shown). Regions flanking the Tn 5 mutated gene sequences also were the same as the sequences of their respective regions in the wild-type $X$. fastidosa Temecula strain, thus confirming the position of the Tn5 insertion in the hypervirulent mutants

A detailed description of the Tn5 insertion site of each of the seven mutants is presented in the following paragraphs.

Mutant PD2118. The Tn5 insertion in PD2118 occurred between the position 2506778 and 2507999 in the genome of the PD strain of $X$. fastidosa (Van Sluys et al. 2003). PD2118 gene has $27 \%$ amino acid identity to the known hemagglutinin HecA protein from Erwinia chrysanthemi (Rojas et al. 2002).

Mutant PD1542. The Tn5 insertion occurred between position 1787044 and 1788265 of the $X$. fastidosa PD genome sequence and the disrupted ORF had $25 \%$ amino acid identity with a glycosyltransferase $(d m t)$ gene that is involved in cell wall synthesis of the bacterium Trichodesmium erythraeum. Glycosyltransferases are involved in lipopolysaccharide (LPS) biosynthesis by adding a sugar onto the O-polysaccharide chain. In some cases, LPS has been shown to be involved in bacterial pathogenesis of plants (Dow et al. 2000) by facilitating the ability of a bacterial pathogen to infect plants (Dow et al. 1995; Kingsley et al. 1993); or, in contrast, bacterial LPS can be recognized by plants to trigger some plant defense-related responses (Erbs and Newan 2003). On deoxycholate-polyacrylamide gel electrophoresis (PAGE) gels, purified LPS from mutant strain Xf1542 grown in vitro did not show any alteration in its LPS profile when compared with LPS from wild-type cells (data not shown).

Mutant PD1198. The transposon was inserted within positions 1394401 and 1395622 of the PD genome sequence. Gene PD1198 had 42\% amino acid identity with an outer membrane receptor protein involved in ferric ion transport or acquisition (bfeA) in Pseudomonas syringae pv. syringae. The use of iron as a cofactor is essential to both pathogenic microorganisms and their hosts and influences the pathogen-host relationship (Schaible and Kaufmann 2004).

Mutant PD0218. In PD0218, Tn5 was inserted between positions 275222 and 276443 , in an ORF that has $25 \%$ amino acid identity with a serine protease, $p s p \mathrm{~B}$, from $P$. brassicacea rum. Serine proteases have been involved in the folding and maturation of secreted proteins, and mutations in such genes lead to a change in the biogenesis of other proteins (Lyon and Caparon 2004).

Mutant PD0680. Tn5 was inserted between positions 833367 and 834588 of the $X$. fastidosa genome sequence. The PD0680 gene product has $26 \%$ amino acid homology with a

Table 1. Polymerase chain reaction primers and strains used in this study

\begin{tabular}{|c|c|c|c|c|}
\hline Primers $\mathrm{a} / \mathrm{mutants}$ & Sequences, characteristics ${ }^{b}$ & Putative gene ${ }^{c}$ & Putative function $^{d}$ & Source \\
\hline \multicolumn{5}{|l|}{ Used to sequence } \\
\hline kan-2 fp-1 & АССТАСАACAAAGCTCТСАТСААСС & $\ldots$ & $\ldots$ & Epicentre Technology \\
\hline Arb1 & GGCCACGCGTCGACTAGTACN $_{10}$ & $\ldots$ & $\ldots$ & Caetano-Anoles 1993 \\
\hline Poforw & CTGGCAGAGCATTACGCTGAC & $\ldots$ & $\ldots$ & This study \\
\hline \multicolumn{5}{|l|}{ Used to confirm } \\
\hline kan-2 rp-1 & GCAATGTAACATCAGAGATTTTGAG & $\ldots$ & $\ldots$ & Epicentre Technology \\
\hline kan- $2 \mathrm{fp}-1^{2}$ & АССТАСАACАAАGCТСТСАТСААСС & & $\ldots$ & Epicentre Technology \\
\hline 6191.2 forw & TGCAACCACGCTGAACA & Glucose kinase, $g l k$ & $\ldots$ & This study \\
\hline $6211.2 \mathrm{rev}$ & GGCATCGACCTCATT & Glucose kinase, $g l k$ & $\ldots$ & This study \\
\hline PD0219 forw & GCTGCACTCCAGATTGAACACTGT & Serine protease, $p s p \mathrm{~B}$ & $\ldots$ & This study \\
\hline PD0217 forw & АCСТАСАССТАСАCСАCTGGA & Serine protease, $p s p$ B & $\ldots$ & This study \\
\hline 23531.2 forw & GATCTACCTGCTGTTGC & Hypothetical protein, PD1244 & $\ldots$ & This study \\
\hline $23551.2 \mathrm{rev}$ & GTGAGGATTATTACGGGTGGTG & Hypothetical protein, PD1244 & $\ldots$ & This study \\
\hline 22281.2 forw & CGCGTGCTCGCTCTTCAAT & Coenzyme F390 synthetase, paaK & $\ldots$ & This study \\
\hline $22311.2 \mathrm{rev}$ & TACCGAATGTGGCTTG & Coenzyme F390 synthetase, paaK & $\ldots$ & This study \\
\hline 11001.2 forw & ATTCACGCTCCATACG & Iron receptor, $b f e \AA$ & $\ldots$ & This study \\
\hline $11021.2 \mathrm{rev}$ & ATGTCGAGTCCTGTTGTG & Iron receptor, $b f e \mathrm{~A}$ & $\ldots$ & This study \\
\hline $13991.2 \mathrm{rev}$ & AACAGAGTGCTAGTCACC & Mannosyltransferase, $d m t$ & $\ldots$ & This study \\
\hline 24521.2 forw & ACGACTTGCATAGCAGTAGC & Mannosyltransferase, $d m t$ & $\ldots$ & This study \\
\hline \multicolumn{5}{|l|}{$X$. fastidiosa mutants } \\
\hline Xf2118 & PD2118::EZ::TN<Kan-2>Tnp & $\ldots$ & HL secreted protein, HxfA & This study \\
\hline Xf1198 & PD1198::EZ::TN<Kan-2>Tnp & $\ldots$ & $\begin{array}{l}\text { Ferric enterobacyin } \\
\text { receptor, BfeA }\end{array}$ & This study \\
\hline Xf1542 & PD1542::EZ::TN<Kan-2>Tnp & $\ldots$ & $\begin{array}{l}\text { Mannosyltransferase (lps } \\
\text { biosynthesis), Dmt }\end{array}$ & This study \\
\hline Xf0218 & PD0218::EZ::TN<Kan-2>Tnp & $\ldots$ & Serine protease, $\mathrm{PspB}$ & This study \\
\hline Xf0680 & PD0681::EZ::TN $<$ Kan-2>Tnp & $\ldots$ & Glucose kinase, Glk & This study \\
\hline Xf0875 & PD0875::EZ::TN<Kan-2>Tnp & $\ldots$ & $\begin{array}{l}\text { Coenzyme F390 synthetase, } \\
\text { PaaK }\end{array}$ & This study \\
\hline Xf1244 & PD1244::EZ::TN<Kan-2>Tnp & $\ldots$ & Hypothetical protein & This study \\
\hline Xf1792 & PD1792::Tn903 kan-2 & $\ldots$ & HL secreted protein, $\mathrm{HxfB}$ & This study \\
\hline Xf1246 & PD1246::EZ::TN $<$ Kan-2>Tnp & $\ldots$ & HL secreted protein & This study \\
\hline
\end{tabular}

\footnotetext{
${ }^{a}$ Primer used to sequence and confirm the Tn5 insertion sites. Primer kan-2 fp- 1 was used for both.

${ }^{\mathrm{b}}$ Primer sequences are presented 5' to 3'. For relevant characteristics, PD number = identification number of open reading frame (ORF) in Pierce's disease strain of Xylella fastidiosa. EZ::TN<kan-2>Tnp $=\mathrm{Tn} 5$ derivative (Epicentre Technologies, Madison, WI, U.S.A.); Tn903 kan-2=kanamycin resistance cassette from EZ::TN<Kan-2>Tnp.

${ }^{c}$ Putative gene function of the ORF based on homology between regions flanking the Tn5 insertion site and other $X$. fastidiosa gene sequences.

${ }^{\mathrm{d}}$ Putative gene function of the ORF based on homology between regions flanking the Tn5 insertion and other X. fastidiosa gene sequences. HL = hemagglutinin-like.
} 
glucose kinase ( $g l k)$ of Brucella melitensis. Glucose kinases are involved in regulatory functions, in addition to their metabolic functions in various organisms (Kwakman and Postma 1994; Park et al. 2000; Wagner et al. 1995). The inactivation of glk was shown to reduce the catabolite repression of several other genes (Spath et al. 1997).

Mutant PD0875. Tn5 was inserted within positions 1084849 and 1086070 . The mutated ORF corresponds to a gene product with $23 \%$ amino acid identity with an anaerobic phenylacetate CoA ligase in Azoarcus evansii, paaK. CoA ligases are involved in regulating methanogenesis in response to changes in the availability of hydrogen (Pennings et al. 1998).

Mutant PD1244. Tn5 was inserted between the positions 1445349 and 1446570 of the PD genome sequence. The ORF 1244 gene product had been annotated as a hypothetical protein in the PD genome sequence (Van Sluys et al. 2003; discussed below).

\section{Sequence analyses of hemagglutinin-like genes in $X$. fastidosa and other plant and animal bacterial pathogens.}

Seven ORFs (PD0986, PD0988, PD1246, PD1792, PD2110, PD2116, and PD2118) have been annotated as hemagglutininlike proteins in the PD X. fastidosa genome sequence (Van Sluys et al. 2003). The gene products PD2118, PD1792 (identified in our study), and PD1246 possessed 27, 37, and 27\% amino acid identities, respectively, with the HecA protein from E. chrysanthemi (GenBank accession number AF501263). The gene products PD2116, PD2110, and PD0988 possessed 34, 35, and 26\% amino acid identities, respectively, with a putative hemagglutinin-related protein from Ralstonia solanaceraum (GenBank accession number Np_522632.1). The last PD X. fastidosa product, PD0986, annotated as a hemagglutinin-like protein (Van Sluys et al. 2003), did not possess any homology with putative hemagglutinin or adhesin proteins from other bacteria.

GenBank comparisons of the conserved hypothetical PD1244 ORF, identified in our mutant study (discussed above), revealed amino acid homology only with putative hemagglutinin-like products Xf2196 and PD2116 from the CVC and PD strain of $X$. fastidosa, respectively (Simpson et al. 2000; Van Sluys et al. 2003). However, the homology among PD1244, Xf2196, and PD2116 occurred only on a small region, 79 amino acids (aa), of these large proteins.

Filamentous hemagglutinin (FHA), the major adhesin of the whooping cough agent Bordetella pertussis, is one of the most efficiently secreted proteins in gram-negative bacteria (Clantin et al. 2004). The 230-kDa FHA is secreted by a TPS system involving a specific outer membrane transporter, FhaC. The FHA-FhaC system has served as a prototype for the definition of the TPS pathway (Jacob-Dubuisson et al. 2001). TPS systems are composed of two separate proteins, with TpsA being the secreted protein and TpsB being its specific transporter (Jacob-Dubuisson et al. 2001). The TPS system has been proposed to belong to the type $\mathrm{V}$ secretion pathway (Henderson et al. 2000; Jacob-Dubuisson et al. 2001), in which secretion involves the translocation of secreted substrates (TpsA) through a $\beta$-barrel structure formed by a specific cognate outer membrane protein (TpsB). The N-proximal secretion domain of the secreted protein (TpsA) is proposed to interact with the secretion partner protein (TpsB), allowing secretion of the unfolded TpsA protein (Henderson et al. 2000; Jacob-Dubuisson et al. 2001). Despite their limited overall sequence similarities, proteins secreted through the TPS pathway share similar "secretion domains" in a 110-aa conserved region in their N-proximal region (Jacob-Dubuisson et al. 2001; Schönherr et al. 1993). TpsB proteins have the characteristic signature of integral outer membrane proteins and a C-terminal amphipathic 10- residue region that likely forms a transmembrane $\beta$-strand (Konninger et al. 1999). Another feature of TPS systems is that genes for both partners typically, but not always, are found adjacent to each other in the same operon (Henderson et al. 2000; Jacob-Dubuisson et al. 2001).

The Tps secretion domains are conserved in HecA, a hemagglutinin protein in $E$. chrysanthemi (GenBank accession number AF501263) (Rojas et al. 2002). We analyzed the first 250 aa in the $\mathrm{N}$-proximal region of the seven gene products that were annotated as hemagglutinin-like proteins in the PD genome sequence (Van Sluys et al. 2003) and aligned them with the hemagglutinin HecA of E. chrysanthemi (Fig. 3). Amino acid sequence analyses of the $\mathrm{N}$-proximal 250-aa sequences of $X$. fastidosa hemagglutinin-like products revealed that the Tps secretion domains were conserved in only three $X$. fastidosa hemagglutinin-like genes, PD2118, PD1792, and PD1246 (Fig. 3). We also noted that the putative hemagglutinin-related protein from $R$. solanaceraum mentioned above did not contain the Tps secretion domains. No conserved domains were identified in the PD1244 protein using the NCBI conserved domain database. Interestingly, PD gene PD1246 has a frameshift or point mutation in its sequence (Van Sluys et al. 2003); thus, we hypothesized that PD1246 most likely was not functional in the Temecula strain, which was further confirmed by our random mutant screening (discussed below).

A BLAST search of the $X$. fastidosa PD genome sequence with known TpsB proteins (Jacob-Dubuisson et al. 2001) revealed one putative TpsB-like gene, PD1933 that is located distant from PD2118, PD1792, and PD1246. By searching the nonredundant database for similar proteins using BLAST, other bacterial proteins with homology to TpsB proteins were found. For example, the PD1933 gene product had $45 \%$ amino acid identity with the known secretion partner FhaC, and their secretion domains shared $92 \%$ amino acid homology. FhaC is an outer membrane protein involved in the secretion of the B. pertussis hemagglutinin by forming small-diameter transmembrane $\beta$-barrels in the outer membrane (Jacob-Dubisson et al. 1999; Konninger et al. 1999). The predicted secondary structure of the PD1933 protein also provides strong evidence that PD1933 is a member of the TpsB family. Analyses using a method based on a hidden Markov model predicts that the C-terminal 400 aa of PD1933 contain a number of $\beta$-structures consistent with the formation of a 20 -stranded $\beta$-barrel as proposed for FhaC by Guedin and associates (2000) (data not shown). Furthermore, the membrane-spanning regions of PD1933 and other secretion partners are likely to be conserved with respect to FhaC, due to specific structural requirements for protein domains that span membranes. No other TpsB homolog was found in the vicinity of PD2118, PD1792, and PD1246.

For the reasons presented above, we chose to name the PD2118 and PD1792 gene products HxfA and HxfB, respectively. Based on its predicted amino acid homology and secondary structures, the PD1933 gene product is a putative TpsB partner secretion of TpsA member HxfA and HxfB proteins.

\section{Hypervirulent mutations altered $X$. fastidosa growth rate and increased movement in planta.}

In vitro growth curves of the Tn5 mutants and wild-type $X$. fastidosa strain showed that PD0875 (paaK), PD0681 (gluP), and PD1542 (dmt) reached their exponential and stationary phases later than the wild type, whereas PD1244 and PD2118 ( $h x f \mathrm{~A})$ reached them earlier (data not shown). Mutant PD1198 (bfeA) reached the exponential and stationary phase in a manner similar to the wild-type $X$. fastidosa strain (data not shown).

The doubling time of Tn5 mutants and the wild-type $X$. fastidosa strain also was determined. The doubling time of the 
wild-type $X$. fastidosa strain was 0.5 day. In contrast, the doubling times of three of the Tn5 mutants (PD0875, PD0681, and PD1542) were longer than the wild-type strain, whereas the doubling time of $h x f$ A (PD2118) and PD1244 mutants was faster than the wild-type strain (Table 2). The doubling time of the PD1198 X. fastidosa mutant was not significantly different from the wild-type strain.

In order to evaluate possible mechanisms that could explain the hypervirulence phenotype, bacterial populations and movement in infected grapevines was assessed for the seven mutants and the wild-type strain. The hypervirulent mutants moved faster in inoculated grapevines than the wild type at $25 \mathrm{~cm}$ above the point of inoculation 12 weeks post inoculation. In contrast, the population of the hypervirulent mutants was not significantly different than the wild type at the point of inoculation (Table 3). The data suggest that hypervirulent cells colonize grapevine tissue more rapidly than wild-type cells.

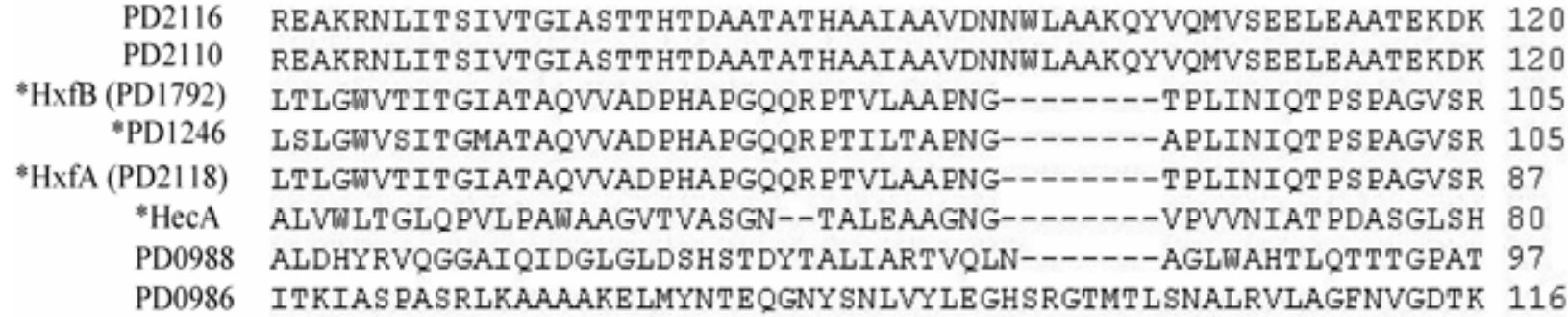

PD2116 GRLEEEKVRAKWREISAR-QDKLTADGLLKGLKE GISNENGLEHLILHPVDVFHELEKI 179 PD2110 GRLEEEKVRAKWREISAR-QDKLTADGLLKGLKE SISNINGLEHLILHPVDVFHELEKI 179 *HxfB (PD1792) NTYQQFDIT PQGAILNN--ART PTQT-HLAGTVQQN PWLAAGTAKIILNEVNS------- 155 *PD1246 NTYQQFDIT PQGAILNN--ART PTQT-HLAGTVQGN PWLAAGTAKIILNEVNS------- 155

*HxfA (PD2118) NTYQQFDIT PQGAILNN--ART PTQT-HLAGTVQGN PWLAAGTAKIILNEVNS------- 137

*HecA NRYHDFNVDNRGLILNNG-TARLTPS-QLGGLIQNN PNLNGRAAAAI LNEVVS------- 131 PD0988 VALDGHPTASLPAPPGDR-PTVALDVSALGGMYAGITLIGTEHGLGVRNAGQLSATS-- 154 PD0986 LEVLAYN PAAEGNRLNTYYAYTKPTHQLGELVTAGIEKLLEITKIASPASRLKAAAAKE 176

\section{NPYGI CXXC}

\begin{tabular}{|c|c|c|c|}
\hline & KVSRMAEALYVGG--DQHAKQF GED & IADVGEALAAA. & \\
\hline PD2110 & LTHPKLLVQLGERAFQELLNKVSRMSEALIVGG--DQHAKQE GED & IADVGEALAAA & \\
\hline HxfB (PD1792) & --------- PTSTQLHGTMEVAG--ARAQLIIANP & CNGCEVINAHQ & \\
\hline *PD1246 & --- PT STQLHGTMEVAG--ARAQLIIAN & $\mathrm{CN}$ & \\
\hline $\mathrm{HxfA}(\mathrm{PD} 2118)$ & $---S T P S Q L H G S M B V A G--A R A Q L I I A$ & ICNGCGV & \\
\hline${ }^{*} \mathrm{Hec} \mathrm{A}$ & --- PNRSRLAGYLEVAG--QAAI & ICs & \\
\hline PD0988 & $------A P L T V T V D G L L E N T$ GRLQSATDTQINA & ANNSGI & \\
\hline PD0986 & -TEQGNYSNLVYLEG-HSRGTMT & SDT & \\
\hline
\end{tabular}

Fig. 3. Alignment of the N-terminal region of seven putative hemagglutinin-like proteins from Xylella fastidiosa and the hemagglutinin protein HecA from Erwinia chrysanthemi. Letters and numbers on the left indicate the name of the $X$. fastidiosa genes as described in the $X$. fastidiosa Pierce's disease genome web site. HxfA and HxfB indicate the newly named X. fastidiosa hemagglutinin proteins, PD2118 and PD1792, respectively. HecA indicates the name of the hemagglutinin protein from E. chrysanthemi (GenBank accession number AF501263). Numbers on the right indicate amino acid residues. The two conserved secretion domains, NPNL and NPYGI, of proteins secreted through the two-partner secretion (TPS) pathway are boxed (Schönherr et al 1993). N, P, L, Y, G, and I indicate asparagine, proline, leucine, tyrosine, glycine, and isoleucine, respectively. Several Tps proteins, including HecA, harbor a CysXXCys motif, which is absent in others. These cysteines (Cys) are not essential for secretion (Schönherr et al 1993). * $=$ Tps secretion domains were conserved in these amino acid sequences.

Table 2. Physiological properties of the Xylella fastidiosa Tn5 mutants and wild-type strain

\begin{tabular}{lcc}
\hline & & Phenotypes $^{\mathbf{a}}$ \\
\cline { 2 - 3 } Genotype & & \multicolumn{1}{c}{ Attachment assay $^{\mathbf{b}}$} \\
\hline Wild type & Doubling time (days) $^{\mathbf{c}}$ & Cell-to-cell aggregation $^{\text {Surface attachment }}$ \\
HxfA (PD2118) & $0.50 \pm 0.018$ & +++ \\
BfeA (Xf1198) & $\mathbf{0 . 4 5} \pm \mathbf{0 . 0 0 5}$ & - \\
Dmt (Xf1542) & $0.48 \pm 0.003$ & ++ \\
PspB (Xf0218) & $\mathbf{0 . 9 3} \pm \mathbf{0 . 0 1}$ & +++ \\
Glk (PD0680) & $\mathbf{N D}$ & +++ \\
PaaK (PD0875) & $\mathbf{0 . 8 8} \pm \mathbf{0 . 1 3}$ & +++ \\
hypothetical (PD1244) & $\mathbf{1 . 1 4} \pm \mathbf{0 . 2 2 4}$ & +++ \\
\hline
\end{tabular}

${ }^{a}$ Data is an average of two independent repetitions (six data points total).

${ }^{\mathrm{b}}$ Frequency of attachment: -, absent; +, low; ++, moderate; +++, high.

${ }^{\mathrm{c}}$ Doubling time calculated as described by Madigan and associates (1970). Significant difference indicated in bold; significance defined as $P<0.01 ;$ ND $=$ not determined (PspB mutant lost in storage). 


\section{HxfA is involved}

in cell-to-cell aggregation in vitro and in planta.

To evaluate whether the hypervirulence phenotype affected cell-to-cell attachment, the ability of each hypervirulent mutant to aggregate in culture was investigated. We first visually assessed cell-to-cell aggregation of each mutant in $125-\mathrm{ml}$ glass Erlenmeyer flasks placed on an orbital shaker. The wildtype $X$. fastidosa strain and six of the Tn5 mutants formed large aggregates when grown in vitro (Fig. 4A; Table 2). In contrast, the hxfA mutant was impaired in its ability to form cell-to-cell aggregates in liquid culture (Fig. 4B; Table 2).

The colony morphology of wild-type and HxfA cells was examined on solid medium. The HxfA mutant exhibited a homogenous distribution of cells, forming a continuous lawn of cells, whereas the wild type grew in separate clumps composed of small and medium-size individual colonies (Fig. 4C and D), further confirming the inability of HxfA cells to selfaggregate.

An optical density assay (Burdman et al. 2000) was used to quantify the effect of the HxfA mutation on cell-to-cell aggregation. This assay further confirmed that cell-to-cell aggregation of the HxfA mutant was decreased (Table 4).

The aggregates of wild-type and $h x f \mathrm{~A}$ mutant cells grown in PD3 medium and in planta were observed by scanning electron microscopy. Wild-type cells grown in vitro were aggregated together typically by cell-to-cell contact along the length of the cells (data not shown). The hxfA mutant cells did not appear to be aggregated in such a manner (data not shown). This result was further observed in planta (Fig. 4). HxfA cells did not form large clumps in the plants, but rather, $h x f \mathrm{~A}$ cells typically formed a monolayer of cells on the surface of the xylem vessels (Fig. 4F and H). In contrast, wild-type cells formed a multiple layer of cells that clearly aggregated to each other (Fig. 4E and G).

\section{HxfA is not involved in surface attachment in vitro.}

Adhesion properties of the hypervirulent mutants were investigated further by examining surface attachment. All seven $X$. fastidosa Tn5 mutants and wild-type cells were grown in liquid PD3 medium in glass Erlenmeyer flasks on an orbital shaker to visualize bacterial aggregates that formed a ring on the inside of the flask. The wild-type $X$. fastidosa strain and six of the seven Tn 5 mutants still were able to attach on the surface of the flasks (Table 2). In contrast, this assay suggested that the ability of the $h x f \mathrm{~A}$ mutant to adhere to a glass surface was slightly reduced (Table 2).

To further quantify the role of HxfA on $X$. fastidosa adhesion to a surface, we used a crystal violet staining assay (Espinosa-Urgel et al. 2000) to assess cell attachment on various surfaces. A slight reduction in surface attachment for the hxfA mutant compared with the wild type was observed; how-

Table 3. Bacterial populations of Thompson seedless grapevines 12 weeks after inoculation with wild-type or Tn5 Xylella fastidiosa cells

\begin{tabular}{lcc}
\hline & \multicolumn{2}{c}{ Populations $($ CFU/g of tissue) } \\
\cline { 2 - 3 } Genotype & At the point & Above the point \\
\hline Wild type & $10.6( \pm 15) \times 10^{6}$ & 0 \\
HxfA (PD2118) & $6( \pm 7) \times 10^{6}$ & $\mathbf{5 . 3}( \pm \mathbf{8}) \times \mathbf{1 0}^{\mathbf{5}}$ \\
BfeA (PD1198) & $4.3( \pm 4.6) \times 10^{6}$ & $\mathbf{4 . 6}( \pm \mathbf{4 . 4}) \times \mathbf{1 0}^{\mathbf{4}}$ \\
Dmt (PD1542) & $36.6( \pm 5.2) \times 10^{6}$ & $\mathbf{3 . 6}( \pm \mathbf{1 . 8}) \times \mathbf{1 0}^{\mathbf{5}}$ \\
Glk (PD0680) & $2.8( \pm 2.6) \times 10^{6}$ & $\mathbf{1 . 4}( \pm \mathbf{0 . 9}) \times \mathbf{1 0}^{\mathbf{7}}$ \\
PaaK (PD0875) & $25( \pm 10) \times 10^{6}$ & $\mathbf{1 . 8}( \pm \mathbf{0 . 1}) \times \mathbf{1 0}^{\mathbf{7}}$ \\
hypothetical (PD1244) & $6.3( \pm 4.5) \times 10^{6}$ & $\mathbf{2 . 4}( \pm \mathbf{1 6}) \times \mathbf{1 0}^{4}$ \\
\hline
\end{tabular}

${ }^{a}$ Data is an average of two independent replications at the point or $25 \mathrm{~cm}$ above the point of inoculation. Significance indicated in bold type; significance was defined as $P<0.01$. ever, the differences were not significantly different (Table 4). Thus, HxfA does not appear to play a central role in X. fastidosa surface attachment in vitro.

\section{Site-directed mutagenesis of $h x f B$ and confirmation of the observed $h \boldsymbol{x} f \mathrm{~A}$ phenotypes.}

To confirm that hemagglutinins are involved in $X$. fastidosa virulence and cell-to-cell aggregation, a mutant in the second
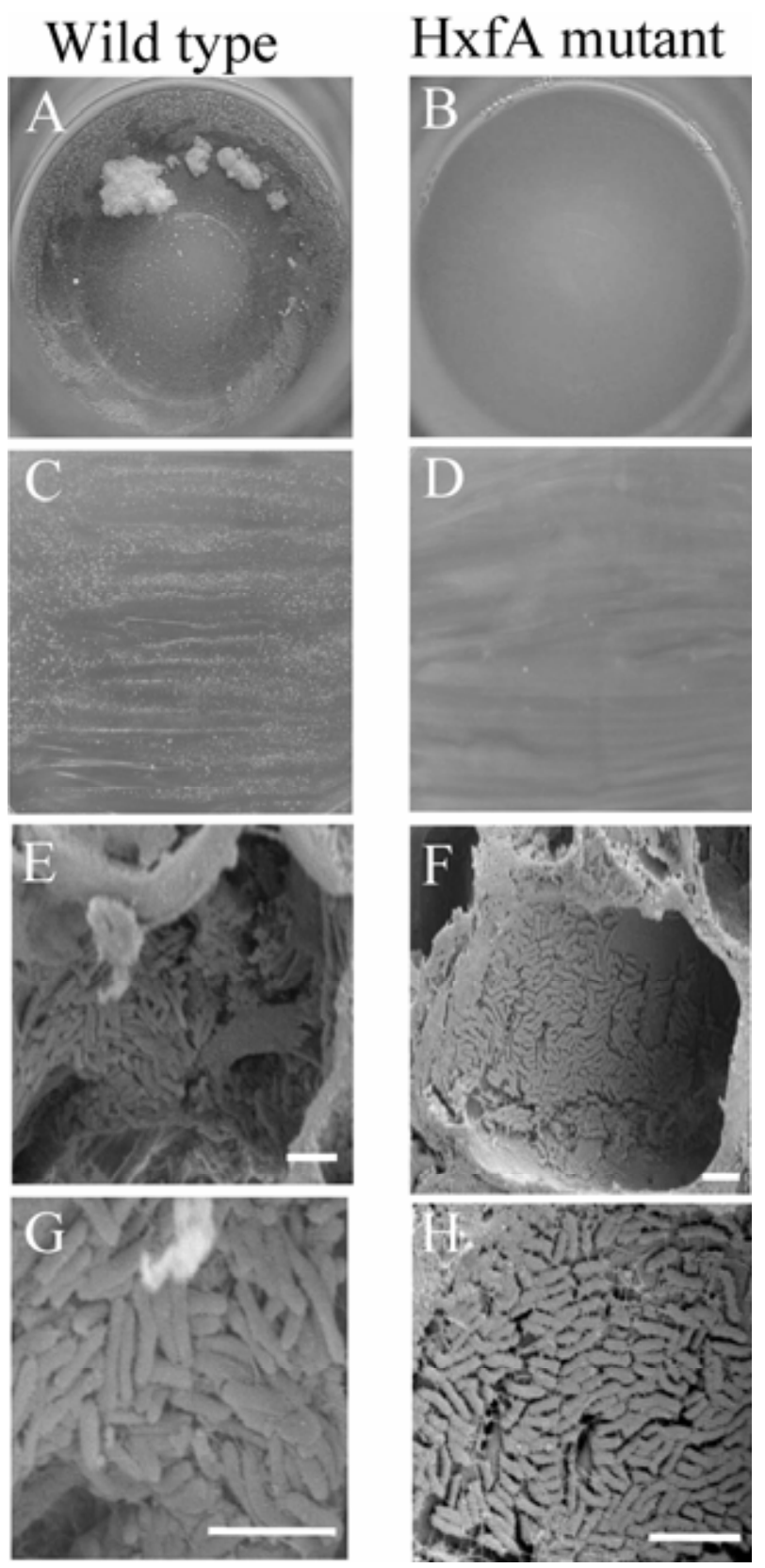

Fig. 4. HxfA-dependent aggregation of Xylella fastidiosa cells in vitro and in planta. A, C, E, and $\mathbf{G}, X$. fastidiosa wild-type cells; $\mathbf{B}, \mathbf{D}, \mathbf{F}$, and $\mathbf{H}, X$. fastidiosa $h x f \mathrm{~A}$ mutant cells. A and $\mathbf{B}$, Wild-type and $h x f$ A mutant cells, respectively, inoculated into PD3 medium in a 125-ml flask and placed on a shaker. The degree of self-aggregation was visualized after 10 days of incubation. $\mathbf{C}$ and $\mathbf{D}$, Wild-type and $h x f$ A mutant cells, respectively, plated onto PD3 medium plates. The colony morphology was examined after 10 days of incubation. $\mathbf{E}$ and $\mathbf{F}$, Wild-type and $h x f$ A cells in xylem vessels. Note the lack of a three-dimensional array in the HxfA mutant compared with the wild type. $\mathbf{G}$ and $\mathbf{H}$, Higher magnification of wild-type and $h x f \mathrm{~A}$ cells in a biofilm. Note that the wild-type cells typically aggregated together side to side, whereas the hxfA mutant cells did not aggregate in this manner. Scale bar equivalent to 5 microns in every panel. 
hemagglutinin identified above, HxfB (PD1792), was generated. The disruption of gene hxfB was confirmed by a PCR procedure (data not shown). The mutated PD1792 strain was inoculated twice into three Chardonnay grapevines and it consistently showed i) earlier symptom development, ii) higher disease score over a period of 32 weeks, and iii) earlier death of the grapevines compared with vines inoculated with wildtype cells (Fig. 2), thus confirming that hemagglutinins are involved in attenuating X. fastidosa pathogenicity. An optical density assay (Burdman et al. 2000) was used to quantify the effect of the HxfB mutation on cell-to-cell aggregation. Results confirmed that HxfB also is involved in X. fastidosa cellto-cell aggregation (Table 4).

An Xf1246 mutant strain was found when insertion sites of mutants from the $X$. fastidosa Tn5 library were identified. The identity and disruption of the gene PD1246 was confirmed by Southern blot analysis. Its cell-to-cell aggregation was not altered (data not shown), supporting the hypothesis that gene PD1246 is not functional in X. fastidosa (discussed above).

\section{DISCUSSION}

The random-mutagenesis approach used here identified seven loci that attenuate $X$. fastidos $a$ virulence in a susceptible host. Our study confirms, for the first time, that screening a random library of Tn5 $X$. fastidosa mutants in susceptible hosts can identify genes mediating $X$. fastidosa pathogenicity. Our study also demonstrates that the two-step procedure presented here, direct PCR on $X$. fastidosa colony and direct sequencing of the PCR product, can rapidly identified $X$. fastidosa Tn5 insertion sites. Despite numerous attempts (Guilhabert and Kirkpatrick 2003; Qin and Hartung 2001), a stable X. fastidosa plasmid for in planta complementation of mutated genes with their wild-type copy has not been developed. Furthermore, given the relatively large number of $X$. fastidiosa mutants involved in this study, the fastidious nature of $X$. fastidiosa, and the long incubation period for symptom development in grapevines, it was not feasible to demonstrate for each mutant that the altered pathogenicity phenotype was caused by the Tn 5 insertion rather than caused by the disruption of a downstream gene expression due to polar effects of the transposon insertion. Nevertheless, one mutant (PD2118) of particular interest (i.e., involved in cell-to-cell attachment, biofilm maturation, and pathogenicity) was chosen for additional genetic analysis, and validation of the agglutination function of PD2118 was confirmed by reengineering the mutation using site-directed mutagenesis in another hemagglutinin gene, PD1792.

There is some controversy about the mechanisms involved in $X$. fastidosa pathogenicity. The rate and extent of $X$. fastidosa colonization correlate with susceptibility of grapevines to PD and symptom development (Fry and Milholland 1990; Hopkins 1985; Purcell and Hopkins 1996). Resistance to $X$. fastidosa infection in grapevines correlates with the restriction of $X$. fastidosa to fewer xylem vessels and a decrease in the ability of $X$. fastidosa to translocate throughout the plant (Fry and Milholland 1990). Newman and associates (2003) also documented that $X$. fastidosa vessel-to-vessel movement is a critical step in systemic infection and disease development. De Souza and associates (2003) showed that a pathogenic CVC strain of $X$. fastidosa had a greater ability to colonize plant tissue than a nonpathogenic strain. The movement of $X$. fastidosa between xylem cells is restrained by xylem pit membrane (Hearon et al. 1980; McCoy 1982; Mollenhauer and Hopkins 1974). Therefore, it is not possible that passive movement in the xylem sap stream would allow X. fastidosa to move systemically throughout grapevines and subsequently reach the high bacterial populations that are found in symptomatic grapevines. Based on these observations, it is presumed that active movement of $X$. fastidosa from one xylem vessel to another one through the production of pit-membrane-degrading enzymes plays a critical role in $X$. fastidosa virulence (Fry et al. 1994; Roper et al. 2002). A previous study suggested that the production of $X$. fastidosa-degrading enzymes was under the control of a diffusible signaling factor, DSF, which is produced in response to cell density (Newman et al. 2004). However, the rpfF mutant produced in that study was able to systemically move and cause severe PD, which suggests that DSF is not needed for the production of pit-membrane-degrading enzymes. In addition, our laboratory has shown that a mutant impaired in its ability to produce DSF still expressed at least one cell-wall-degrading enzyme (M. C. Roper, unpublished data).

Symptoms of water stress in grapevines affected by PD occur when the xylem system becomes occluded by tyloses produced by plants, by gums of unknown origin, and by bacterial masses (Fry and Mollenhauer 1990; Hopkins et al. 1974; Mollenhauer and Hopkins 1974; Roper et al. 2003; Stevenson et al. 2004). X. fastidosa characteristically is embedded in an extracellular translucent matrix, thought to be made of EPS that form aggregated biofilms within xylem vessels (Marques et al. 2002; Purcell and Hopkins 1996). Previous studies suggest a correlation between loss of virulence and X. fastidosa aggregation within xylem vessels (De Souza et al. 2003; Hopkins 1985; Koide et al. 2004).

\section{Antivirulence and pathogenicity.}

Historically, pathogenesis research has focused on the identification and characterization of virulence factors. Recently, a new class of genes has been recognized as antivirulence genes (Foreman-Wykert and Miller 2003). Disruption of antivirulence genes increases pathogen virulence and overall fitness (Foreman-Wykert and Miller 2003). Antivirulence genes in Leishmania major maximize the probability of transmission (Cunningham et al. 2001) and facilitate survival in a nonhost environment in Salmonella enterica (Mouslim et al. 2002).

In contrast to our finding, other studies showed that mutations in several of the bacterial genes we identified, including hemagglutinin, serine protease, ferric receptor, and LPS, decreased virulence or colonization in other plant and animal hosts, suggesting that these genes have a different role in dis-

Table 4. Cell-to-cell aggregation and cell-surface attachment of Xylella fastidiosa wild-type, $h x f \mathrm{~A}$, and $h x f \mathrm{~B}$ Tn 5 mutants ${ }^{\mathrm{a}}$

\begin{tabular}{|c|c|c|c|c|}
\hline \multirow[b]{2}{*}{ Genotype } & \multirow[b]{2}{*}{ Cell-to-cell aggregation ${ }^{c}$} & \multicolumn{3}{|c|}{ Cell-surface attachment on indicated surface ${ }^{b}$} \\
\hline & & Glass & Polystyrene & Polypropylene \\
\hline Wild type & $36.2 \pm 8.9$ & $0.9 \pm 0.7$ & $0.07 \pm 0.02$ & $0.25 \pm 0.04$ \\
\hline HxfA (PD2118) & $8.9 \pm 6.5$ & $0.5 \pm 0.3$ & $0.06 \pm 0.01$ & $0.20 \pm 0.03$ \\
\hline HxfB (PD1792) & $9.2 \pm 1.0$ & ND & ND & ND \\
\hline
\end{tabular}


ease development for $X$. fastidosa (Cotter et al. 1998; Dow et al. 1990; Lyon and Caparon 2004; Newman et al. 2002; Rojas et al. 2002). We hypothesized that HxfA and HxfB hemagglutinin proteins facilitate $X$. fastidosa self-aggregation and attenuate $X$. fastidosa pathogenicity by limiting its colonization capacity, which reduces the rate of xylem vessel occlusion. Our results also suggest that the plant host may recognize $X$. fastidosa LPS and respond with defense mechanisms that slow its colonization (Erbs and Newan 2003). An in planta modification of $X$. fastidosa LPS structure might be modulated in response to host-derived signals, a phenomenon well known in other bacterial systems (Kannenberg et al. 1994; Skurnik and Toivanen 1993). Such a hypothesis would explain why we did not see any differences in LPS composition between the wildtype and Xf1542 mutant strains growing in vitro.

The potential role of the other five ORFs in attenuating $X$. fastidosa pathogenicity remains unclear. The hypothetical ORF PD1244 is in the vicinity of other conserved hypothetical genes in the PD strain. Its function in X. fastidosa remains unknown. Mutagenesis analysis of the other conserved hypothetical genes that are in the vicinity of PD1244 may clarify the function of these genes in $X$. fastidosa.

Antivirulence genes may provide the most advantageous balance between pathogenicity and symbiosis in order to increase its chance of survival in a plant host and its probability of insect transmission to new plant hosts. Analysis of the insect transmissibility of the hypervirulent mutants may further clarify the functions of these X. fastidiosa genes.

\section{Movement and pathogenicity.}

Motility solves many of the problems that confront microbes: it allows them to obtain nutrients, avoid toxic substances or unfavorable environments, and find a host. Motility contributes to the virulence of various plant-pathogenic bacteria in the early stages of host plant invasion and colonization (Bayot and Ries 1986; Hatterman and Ries 1989; Hawes and Smith 1989; Panapoulos and Schroth 1974; Tans-Kersten et al. 2001). However, in contrast to animal pathogens (Ottemann and Miller 1997), the role of movement in plant-associated bacteria is not as well understood (VandeBroek and Vanderleyden 1995).

Our observations support previous reports that movement is a key component of $X$. fastidosa pathogenicity (De Souza et al. 2003; Hopkins 1985). Hypervirulence associated with the HxfA and HxfB mutants suggests that, because $X$. fastidosa cells are reduced in their ability to self-aggregate and are planktonic cells, they are freer to move within the xylem vessels and, subsequently, colonize other vessels more rapidly than the wild-type cells. We hypothesize that the monolayered biofilm observed in vines inoculated with the HxfA mutant would be sufficient to reduce water transport from one xylem element to another. In addition, the presence of mutant cells likely would still trigger plant-defense response such as tyloses and gels formation in the effort to limit pathogen colonization (Clerivet et al. 2000; Stevenson et al. 2004), which would further contribute to xylem blockage.

Attachment and LPS genes may have evolved to enhance colonization of specific plant hosts, thus mediating $X$. fastidiosa-plant host interactions. For example, among the genes that showed a higher degree of divergence between the PD and CVC strains, genes involved in the production of fimbrillin and hemagglutinin were identified (Van Sluys et al. 2003). These genes most likely play a role in $X$. fastidosa cell attachment. Furthermore, one of the genes found in the $X$. fastidosa CVC strain but absent in the $X$. fastidosa PD strain is an Oantigen acetylase, which is involved in LPS modification (van Sluys et al. 2003). Kingsley and associates (1993) showed that LPS were involved in Xanthomonas campestris pv. citrumelo host range. However, recent work has shown that CVC strains can infect and cause a mild PD-like disease in $V$. vinifera $(\mathrm{Li}$ et al. 2002), suggesting that attachment and LPS genes alone do not mediate host specificity.

Possible mechanisms involved in producing the hypervirulent phenotype of the other mutants identified in this study are unknown; however, their enhanced movement and virulence demonstrates that movement is important in Xylella fastidosa pathogenicity and disease development.

\section{Attachment and pathogenicity.}

In contrast to bacterial infections in mammals (Sohel et al. 1993; Strom and Lory 1993), the relative importance of adhesion in plant-pathogenic bacteria has remained controversial (Beattie and Lindow 1994). One exception is Agrobacterium tumefaciens, where it is clear that attachment to plant cells is a prerequisite for efficient plant transformation and disease development (Matthysse and McMahan 1998).

Plant-pathogenic bacteria have been shown to produce a variety of potential fimbrial and nonfimbrial adhesins (Rojas et al. 2002; Van Sluys et al. 2003). Fimbrial adhesins, fimbriae, and type IV pili have been shown to contribute to the virulence and attachment of various bacteria (Kang et al. 2002; OjanenReuhs et al. 1997; Romantschuk and Bamford 1986; van Doorn et al. 1994). Two nonfimbrial adhesins, HecA from $E$. chrysanthemi and XadA from Xanthomonas oryzae pv. oryzae, are involved in virulence (Ray et al. 2002; Rojas et al. 2002). HecA from E. chrysanthemi also is involved in self-aggregation and surface attachment (Rojas et al. 2002).

The PD Xylella fastidosa genome contains multiple putative fimbrial and afimbrial adhesins, such as EPS, typeIV fimbriae, and hemagglutinin-like proteins (Van Sluys et al. 2003). De Souza and associates (2003) showed that the expression of a
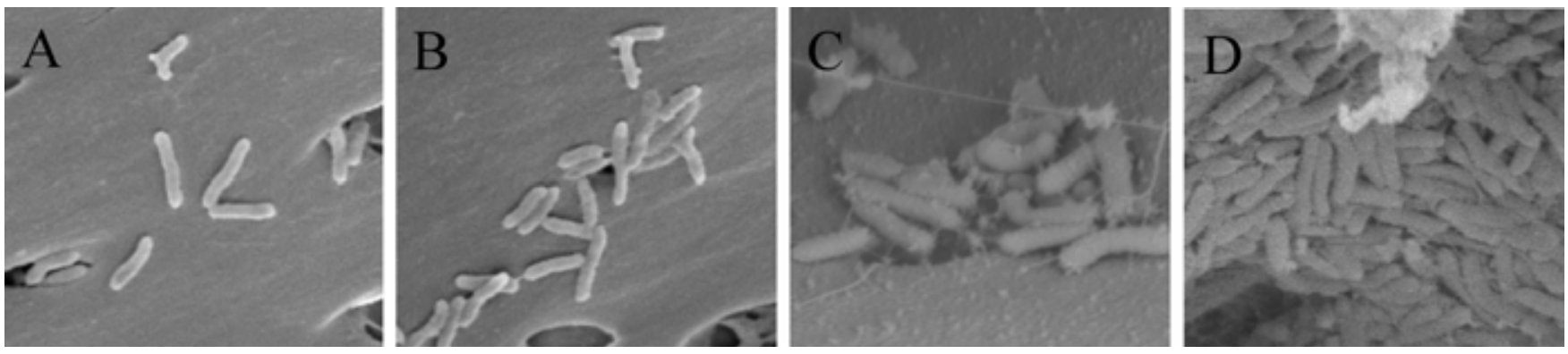

Fig. 5. Model of possible mechanisms involved in Xylella fastidiosa adhesion to xylem vessels of grapevines. A, X. fastidiosa bacteria attach to the surface, probably using fimbrial and nonfimbrial adhesins other than FimA, FimF, and hemagglutinins (this study, Feil et al. 2003); B, HxfA, HxfB, and other adhesins mediate secondary contact between $X$. fastidiosa cells, which leads to $\mathbf{C}$, microcolony formation. Based on our results, hemagglutinins appear to be important mediators for cell-cell aggregation. D, Bacterial cells finally aggregate to each other via hemagglutinins HxfA and HxfB, fimbriae, and exopolysaccharides to form matured biofilms within the xylem vessels (this study, Feil et al. 2003). 
fimbriae gene, fim A, was upregulated in a pathogenic CVC strain of X. fastidosa, whereas Koide and associates (2004) showed that a fimbrial adhesion precursor was absent in a nonpathogenic CVC strain of $X$. fastidosa. However, mutations in fimbriae products FimA and FimF did not alter the pathogenicity and surface attachment of X. fastidosa (Feil et al. 2003). In contrast, cell-to-cell aggregation seemed reduced in $\operatorname{fim} \mathrm{A}$ and fim $\mathrm{F}$ mutants of $X$. fastidosa compared with the parental strain (Feil et al. 2003).

Our results suggest that hemagglutinins HxfA and HxfB (PD2118 and PD1792, respectively) in PD strains of X. fastidosa play a major role in biofilm maturation. De Souza and associates (2004) recently showed that the expression of the CVC gene $\mathrm{Xf0889}$, homolog to $\mathrm{PD}$ gene $h x f \mathrm{~B}$, was upregulated during biofilm formation in vitro. Based on the phenotype of the $X$. fastidosa $\mathrm{HxfA}$ and $\mathrm{HxfB}$ mutants, we propose the following model for attachment to xylem vessels (Fig. 5). The first attachment process most likely involves fimbrial and nonfimbrial adhesins, other than FimA and FimF and hemagglutinins HxfA and $\mathrm{HxfB}$ (Tables 2 and 4; Figs. 4F and $\mathrm{H}$ and 5A) (Feil et al. 2003), because hemagglutinin and fimbriae mutants can still attach to xylem walls. HxfA and HxfB adhesins then are involved in the secondary contact (Fig. 5B) between $X$. fastidosa cells mediating microcolony formation (Fig. 5C). Finally, bacterial cells aggregate to each other via hemagglutinins, fimbriae, and, most probably, EPS to form a mature biofilm within the xylem vessels (Tables 2 and 4; Figs. 4 and 5D) (Feil et al. 2003). Hemagglutinins appear to be essential for cell-to-cell aggregation. Because mutations in either $h x f \mathrm{~A}$ or $h x f \mathrm{~B}$ alter $X$. fastidosa aggregation, we hypothesize that both $\mathrm{HxfA}$ and $\mathrm{HxfB}$ proteins need to be functional to allow $X$. fastidosa self-attachment, and it is quite possible that cell aggregation is mediated by a direct interaction between HxfA and HxfB proteins. However, it is likely that other surface proteins besides hemagglutinins and fimbriae are involved in surface adhesion.

Our study of random Tn $5 X$. fastidosa mutants represents an unbiased strategy for identifying $X$. fastidosa genes involved in plant pathogenicity. Results indicate that $X$. fastidosa has active mechanisms to attenuate its virulence in planta, and that movement is a key component of $X$. fastidosa disease development. Our study also contributes to better understanding the importance of attachment and xylem blockage in X. fastidosa pathogenicity.

\section{MATERIALS AND METHODS}

\section{Bacterial strains, growth conditions, and primers.}

The PD X. fastidosa strain Temecula was isolated and stored as previously described (Guilhabert et al. 2001). For all experiments, the wild-type and Tn5 Temecula $X$. fastidosa mutants were grown at $28^{\circ} \mathrm{C}$ in PD3 medium (Davis et al. 1981) with or without kanamycin at $5 \mu \mathrm{g} / \mathrm{ml}$. For the growth, aggregation, adhesion, and colony morphology assays, $X$. fastidosa cells, previously seeded on PD3 plates, were harvested, transferred into 2 $\mathrm{ml}$ of PD3 liquid medium, and adjusted to optical density at 600 $\mathrm{nm}\left(\mathrm{OD}_{600}\right)=0.25\left(10^{8}\right.$ cells $\left.\mathrm{ml}^{-1}\right)$. The adjusted $X$. fastidosa suspension was diluted 1:100 with fresh PD3 medium and used for all growth kinetics, adhesion, and colony morphology assays. Culture volumes did not exceed $20 \%$ of the capacity of the flasks or tubes to ensure adequate aeration of the culture. The cultures were established in duplicate. All the PCR and sequencing primers used in this study are presented in Table 1.

\section{Random transposon mutagenesis, identification of mutated genes, and sequence analysis.}

All the $X$. fastidosa mutants are described in Table 1. Electrocompetent $X$. fastidosa Temecula cells were prepared as previously described (Guilhabert and Kirkpatrick 2003). The $X$. fastidosa Temecula strain was mutagenized using the transposome protocol previously described (Guilhabert et al. 2001) and a random insertion library of 1,000 Tn5 X. fastidosa mutants was generated.

After assessing pathogenicity in greenhouse-grown grapevines (discussed below), the Tn5 insertion site of the mutants exhibiting enhanced virulence (hypervirulent $X$. fastidosa mutants) was identified by a two-step procedure. The chromosomal region flanking the Tn5 element first was amplified using an oligonucleotide, Poforw, that binds specifically to the transposon sequence in combination with a degenerate primer, Arb1, that anneals to sequences flanking the Tn5 insertion. Then, following PCR amplification, direct sequencing was accomplished using a second oligonucleotide, kan-2 fp- 1 that primes the PCR fragment downstream of Poforw near the right border of the transposon (Chun et al. 1997; Hermann et al. 2000). One colony of each Tn5 X. fastidosa mutant was transferred into $10 \mu \mathrm{l}$ of deionized water and $3 \mu \mathrm{l}$ of the suspension was used as template in the PCR reaction. All PCR reactions were conducted with conditions described by Hermann and associates (2000) using a Taq DNA polymerase (Promega Corps., Madison, WI, U.S.A.) diluted in a TaqStar antibody (BD Biosciences Clontech, Palo Alto, CA, U.S.A.). Only the first step of a modified two-step PCR protocol was used (Chun et al. 1997). Briefly, the first 12 cycles included an annealing step of $30 \mathrm{~s}$, initially at $36^{\circ} \mathrm{C}$, then increasing $1^{\circ} \mathrm{C}$ per cycle; the last 25 cycles included a primer-annealing step of $30 \mathrm{~s}$ at $65^{\circ} \mathrm{C}$. After amplification, the PCR products were purified using the Qiaquick PCR purification kit (Qiagen, Valencia, CA, U.S.A.) and were sequenced in a $2 \mathrm{X}$ Big Dye Terminator sequencing reactions (Applied Biosystems, Foster City, CA, U.S.A.), using the outward primer kan-2 fp-1 by the Division of Biological Sciences DNA sequencing facility at the University of California, Davis.

Tn5 insertion sites were confirmed using, as forward primers, kan- 2 fp- 1 and kan- 2 rp- 1 that bind close to the right and left borders of the transposome, respectively, and reverse primers derived from the sequences we obtained in the mutated ORF. The identity of the two putative hemagglutinin mutated genes, PD2118 and PD1246, was confirmed further by Southern Blot analysis (discussed below). All PCR reactions were conducted and cycled with standard conditions (Smart et al. 1996). The 35 cycles of PCR included an annealing step of 1 min at $58^{\circ} \mathrm{C}$. The resulting PCR products were sequenced to further confirm the location of the Tn 5 insertion sites.

DNA sequences were analyzed with the program Bioedit (version 5.0.6; Tom Hall, North Carolina State University, Department of Microbiology) and database searches were performed with the BLAST program accessed through the National Center for Biotechnology Information (NCBI) (Altschul et al. 1990). GenBank comparisons in the NCBI conserved domain were performed to identify conserved domains in hypothetical proteins. The CLUSTALW method (Thompson et al. 1994) was used for the protein alignments.

\section{Site-directed mutagenesis.}

A 680-bp region of $X$. fastidosa Temecula genome, including a small coding sequence of the PD1792 gene, was amplified using primers PD1792rev and PD1792forw and cloned into the pCR 2.1-TOPO vector (Invitrogen, Carlsbad, CA, U.S.A.). The plasmid then was digested with EcoRI and the PD1792 insert was ligated into EcoRI-digested pUC18 plasmid, creating pXF012. Plasmid pXF012 was linearized at the unique restriction site $B s t \mathrm{BI}$ of the cloned, PCR-amplified PD1792 fragment. Two annealed BstBI adaptators carrying a 
MfeI restriction site (5'-CAATTGACGT-3') were ligated in BstBI-digested pXF012. The Tn903 kanamycin resistance gene (Guilhabert et al. 2001) was cloned into pXF012 digested with $\mathrm{MfeI}$ to make pXF013. Insert and junction sequences of pXF013 were determined. pXF013 plasmid DNA $(2 \mu \mathrm{g})$ was electroporated into $X$. fastidosa and transformants were selected as described (Guilhabert et al. 2001). Disruption of the PD1792 locus was confirmed by using the Expand Long Template PCR system (Roche, Mannheim, Germany) with primers PD1791rev and PD1793forw binding to the flanking ORFs of the mutated PD1792 gene. Briefly, the annealing temperature in both cycles was $58^{\circ} \mathrm{C}$ and the elongation times in the first and second set of cycle were $4 \mathrm{~min}$ for 10 cycles and $4 \mathrm{~min} 20 \mathrm{~s}$ per cycle for 25 cycles, respectively. The identity of the PCR product was confirmed using HindIII that cuts only once into the Tn903 kan-2 cassette.

\section{Southern blot analysis of putative $X$. fastidiosa mutants.}

$X$. fastidosa genomic DNAs were isolated from the mutant strains as described (Zhang et al. 1998). Genomic DNAs from the transformants obtained by random mutagenesis were individually digested by the two restriction enzymes, EcoRI and EagI. PD2118 and PD1246 genes are highly homologous to each other. To confirm the identity of the two random hemagglutinin PD2118 and PD1246 mutant strains, their genomic DNAs were digested with SalI and XmnI. All digested DNAs were electrophoresed, alkali denatured, and transferred to a nitrocellulose membrane as previously described (Guilhabert et al. 2001). Tn5 DNA was PCR amplified, purified, and used as a hybridization probe in Southern blot analyses of genomic DNAs from the X. fastidosa mutants (Guilhabert et al. 2001). Tn5 DNA (25 ng) was labeled with fluorescein dye using the Gene Images random prime labeling module kit (Amersham Biosciences, Bucks, U.K.). Hybridizations and detection were carried out according to the recommendations of the Gene Images CDP-Star detection module kit (Amersham Biosciences). Stringent posthybridization wash conditions (15 min per wash) were once in $1 \times \mathrm{SSC}(1 \times \mathrm{SSC}$ is $0.15 \mathrm{M} \mathrm{NaCl}$ plus $0.015 \mathrm{M}$ sodium citrate) and $0.1 \%$ sodium dodecyl sulfate (SDS) at $60^{\circ} \mathrm{C}$ and once in $0.5 \times \mathrm{SSC}$ and $0.1 \% \mathrm{SDS}$ at $68^{\circ} \mathrm{C}$.

\section{Pathogenicity assays.}

Each Tn5 X. fastidosa mutant was inoculated individually into Chardonnay, Chenin Blanc, and Thompson seedless grapevines to assess pathogenicity. We first screened all 1,000 Tn5 $X$. fastidosa mutants in Chardonnay for altered symptom development. This screen identified seven $X$. fastidosa Tn $5 \mathrm{mu}-$ tants that showed a pronounced hypervirulence phenotype 21 weeks after inoculation (i.e., grapevines inoculated with these Tn5 mutants developed more severe disease symptoms than did vines inoculated with the wild-type Temecula strain). In order to confirm their hypervirulence phenotype, we retested in a similar manner the seven mutants and wild-type controls for i) earlier symptom development, ii) more severe symptom development during a period of 32 weeks, and iii) earlier death of the inoculated grapevines. The disease progression of the seven mutants and wild-type controls was performed in three plants each of Chardonnay, Chenin Blanc, and Thompson seedless grapevines (nine plants total for each mutant). The Xf1792 mutant strain was tested twice in a similar manner in three Chardonnay grapevines (six plants total).

Inoculum was prepared from plates of PD3 medium (with or without kanamycin) seeded with wild-type or mutated $X$. fastidosa cells. After 10 to 12 days at $28^{\circ} \mathrm{C}, X$. fastidosa cells were harvested and transferred into $2 \mathrm{ml}$ of sterile deionized water, and the suspension was adjusted to $\mathrm{OD}_{600}=0.25\left(10^{8}\right.$ cells $\left.\mathrm{ml}^{-1}\right)$.
Two 20- $\mu$ l drops of the $X$. fastidosa suspensions were used to inoculate two canes on each grapevine using a pinprick inoculation procedure (Hill and Purcell 1995; Purcell and Saunders 1999). The parental Temecula strain served as a positive control and a water inoculation served as a negative control. The 6-month-old vines were grown in a greenhouse using a nutrient-supplemented drip-irrigation system. Beginning 2 months after inoculation, the vines were observed for symptom development approximately every 2 weeks for 6 more months (32 weeks total after inoculation). The symptoms were rated on a visual scale from 0 to 5 (Fig. 1), where $0=$ no scorched leaves and no abscised leaf blades (healthy), $1=$ only one or two leaves with the scorching symptom starting on the margins of the leaves, 2 = two to three leaves with more developed scorching, 3 = all the leaves with some scorching and a few attached petioles whose leaf blades had abscised (matchsticks), $4=$ all the leaves with heavy scorching or numerous matchsticks, and 5 = leaves only at the end of the cane and numerous matchsticks.

\section{LPS gel analysis.}

LPS fractions were prepared using a protocol described by DeLoney and associates (2002). Briefly, X. fastidosa Tn5 mutant Xf1542 and wild-type cells grown for 7 to 10 days in PD3 medium were harvested by centrifugation, extracted with hot phenol, and desalted by using MicroSpin G-25 columns (Amersham Biosciences). The volume was reduced and the isolated LPS fractions were resuspended in $20 \mu \mathrm{l}$ of sample buffer $(0.3 \%$ Tris Base, $0.2 \%$ glycerol, $0.05 \%$ Bromophenyl Blue), separated by deoxycholic acid-PAGE on $18 \%$ acrylamide using a bilayer stacking gel, and silver stained (Inzana and Apicella 1999; Tsai and Frash 1982).

\section{$X$. fastidosa growth curves and} in planta bacterial population determinations.

In vitro growth curve determinations were performed in 15$\mathrm{ml}$ polystyrene tubes containing $3 \mathrm{ml}$ of PD3 medium. In all, 14 tubes were prepared for the wild type and each Tn 5 mutant, so as to allow destructive sampling of two tubes at every sampling time. Two independent growth curve determinations were performed. Due to the aggregate nature of $X$. fastidosa liquid cultures, immediately after inoculation and after 2, 4, 6, 8,12 , and 16 days the cultured cells were completely dispersed using a tissue homogenizer (Heidolph RzR 50) and the cell growth was monitored by measuring turbidity at $\mathrm{OD}_{600}$. The doubling time of the bacterial populations was calculated using a standard equation (Madigan et al. 1970).

The bacterial populations (number of cells per gram of petiole tissue) of the $X$. fastidosa wild-type and Tn 5 mutants inoculated into Chardonnay vines were determined in the following manner: 14 weeks after inoculation, petiole tissues from each vine inoculated with either a Tn5 mutant or wildtype $X$. fastidosa cells were harvested at the point of inoculation and $25 \mathrm{~cm}$ above the point of inoculation. Petiole tissues were surface sterilized ( $1 \mathrm{~min}$ in $0.6 \%$ sodium hypochlorite and $1 \mathrm{~min}$ in $80 \%$ ethanol), rinsed three times in sterile deionized water, and ground in $2 \mathrm{ml}$ of sterile phosphate-buffered saline buffer using a grinding machine (Bioreba AG, Basel, Switzerland). Serial dilutions were prepared and three replicates of $10 \mu \mathrm{l}$ each were plated on PD3 agar medium with or without kanamycin. After incubating for 7 to 10 days at $28^{\circ} \mathrm{C}$, the number of bacteria was quantified.

\section{Surface attachment, cell-to-cell aggregation, and colony morphology assays.}

The Tn 5 mutants or wild-type $X$. fastidosa cells were grown in $25 \mathrm{ml}$ of PD3 medium in 125-ml glass Erlenmeyer flasks on 
an orbital shaker at $120 \mathrm{rpm}$ to visualize the formation of bacterial cell clumps within the liquid medium and the formation of aggregated cells that attached to the inside of the flask (Marques et al. 2002).

Additional surface attachment and aggregation assays were performed in polystyrene $(15 \mathrm{ml}$; Falcon 2051 tubes; Becton Dickinson Labware, Oxnard, CA, U.S.A.), polypropylene (5 ml; Falcon 2063 tubes, Becton Dickinson Labware), and borosilicate glass $(10 \mathrm{ml})$ tubes containing PD3 medium. The cultures were incubated at $28^{\circ} \mathrm{C}$ in a vertical position without shaking for 10 days. Attachment on the surface walls of the tubes was assessed by a crystal violet staining method (Espinosa-Urgel et al. 2000; Leite et al. 2004). Briefly, after the incubation period, the PD3 medium was discarded and a $1 \%$ (wt/vol) aqueous solution of crystal violet was added to each tube, allowed to incubate for $15 \mathrm{~min}$, then rinsed with deionized water. The remaining stain was eluted from the bacterial ring by ethanol. The absorbance of the ethanol-crystal violet solution was measured at $600 \mathrm{~nm}$.

The cell-to-cell aggregation assay was performed as described by Burdman and associates (2000) and Leite and associates (2004). After 10 days of static incubation, the X. fastidosa cultures were gently agitated and the aggregates were allowed to settle for $20 \mathrm{~min}$. The turbidity of the remaining upper culture medium, composed mostly of dispersed cells, was measured using a spectrophotometer at $540 \mathrm{~nm}$. The culture medium was returned to the original tube, the aggregate masses were dispersed using a tissue homogenizer (Heidolph RzR 50) for 1 min, and the total cell culture was measured (ODt). Relative percentage of aggregated cells was estimated as follows: percent aggregated cells $=($ Odt - ODs $) / O D t \times 100($ Burdman et al. 2000).

The colony morphology of the wild-type or mutant cells was assessed by plating $100 \mu \mathrm{l}$ of a $10^{8} \mathrm{CFU} / \mathrm{ml}$ solution onto two PD3 plates (four plates total). Colony morphology of the mutants was compared with the wild type after 10 days of growth at $28^{\circ} \mathrm{C}$.

\section{Scanning electron microscopy.}

We examined $X$. fastidosa wild-type and mutant cells in grapevine xylem or grown in PD3 broth using scanning electron microscopy. Petiole samples were collected from symptomatic grapevines 3 months after inoculation. Petiole sections and bacterial aggregates, harvested by centrifugation from $X$. fastidosa liquid cultures grown in a glass Erlenmeyer flask, were fixed overnight in a $2.4 \%$ glutaraldehyde, $0.3 \%$ paraformaldehyde solution. Fixed samples then were dehydrated by increasing concentrations of ethanol, critically point dried in a Tousimis Samdri-780A, placed on aluminum specimen mounts with carbon conductive tabs, and sputter-coated with gold using a Denton Vacuum Desk II cold sputter-etch unit. The morphology of the mutant or wild-type $X$. fastidosa grown in grapevines or PD3 broth was observed at 5 to $12 \mathrm{kHz}$ with a Hitachi S-3500N scanning electron microscope and images were recorded digitally.

\section{ACKNOWLEDGMENTS}

This work was supported by the American Vineyard Foundation, the Viticulture Consortium Grants Program of the United States Department of Agriculture-Agricultural Research Service, and the California Department of Food and Agriculture Agreement No. 01-0712. We wish to thank V. Stewart and D. Cook for their advice. We thank J. Stevenson for his help with the scanning electron microscopy; C. Whistler for the LPS gel analysis, the helpful discussions during the course of this work, and the critical review of this manuscript; and N. Hernandez and M. Shuplock for their help with the maintenance of the grapevines and greenhouses.

\section{LITERATURE CITED}

Altschul, S. F., Gish, Miller, W., Myers, E. W., and Lipman, D. J. 1990 Basic local alignment search tool. J. Mol. Biol. 215:403-410.

Bayot, R. G., and S. M. Ries. 1986. Role of motility in apple blossom infection by Erwinia amylovora and studies of fire blight control with attractant and repellent compounds. Phytopathology 76:441-445.

Beattie, G. A., and Lindow, S. E. 1994. Epiphytic fitness of phytopathogenic bacteria: Physiological adaptations for growth and survival. Curr. Top. Microbiol. Immunol. 192:1-27.

Bhattacharyya, A. Stilwagen, S., Reznik, G., Feil, H., Feil, W. S., Anderson, I., Bernal, A., D’Souza, M., Ivanova, N., Kapatral, V., Larsen, N., Los, T., Lykidis, A., Selkov, E., Jr., Walunas, T. L., Purcell, A., Edwards, R. A., Hawkins, T., Haselkorn, R., Overbeek, R., Kyrpides, N. C., and Predki, P. F. 2002. Draft sequencing and comparative genomics of $X y$ lella fastidiosa strains reveal novel biological insights. Genome Res. 10:1556-1563.

Burdman, S., Jurkevirtch, E., Soria-Diaz, M., E. Serrano, A. M., and Okon, Y. 2000. Extracellular polysaccharide composition of Azospirillum brasilense and its relation with cell aggregation. FEMS (Fed. Eur. Microbiol. Soc.) Microbiol. Lett. 189:259-264.

Chun, K. T., Edenberg, H. J., Kelley, M. R., and Goebl, M. G. 1997. Rapid amplification of uncharacterized transposon-tagged DNA sequences from genomic DNA. Yeast 13:233-240.

Clantin, B., Hodak, H., Willery, E., Locht, C., Jacob-Dubuisson, F., and Villeret, V. 2004. The crystal structure of filamentous hemagglutinin secretion domain and its implications for the two-partner secretion pathway. Proc. Natl. Acad. Sci. U.S.A. 101:6194-6199.

Clerivet, A., Deon, V., Alami, I., Lopez, F., Geiger, J. P., and Nicole, M. 2000. Tyloses and gels associated with cellulose accumulation in vessels are responses of plane tree seedlings (Platanus $\times$ acerifolia) to the vascular fungus Ceratocystis fimbriata $\mathrm{f}$. sp. platani. Trees 15:25-31.

Cotter, P. A., Yuk, M. H., Mattoo, S., Akerley, B. J., Boschwitz, J., Relman, D. A., and Miller, J. F. 1998. Filamentous hemagglutinin of Bordetella bronchiseptica is required for efficient establishment of tracheal colonization. Infect. Immun. 66:5921-5929.

Cunningham, M. L., Titus, R. G., Turco, S. J., and Beverley, S. M. 2001. Regulation of differentiation to the infective stage of the protozoan parasite Leishmania major by tetrahydrobiopterin. Science 292:285287.

da Silva, F. R., Vettore, A. L., Kemper, E. L., Leite, A., and Arruda, P. 2001. Fastidian gum: The Xylella fastidiosa exopolysaccharide possibly involved in bacterial pathogenicity. FEMS (Fed. Eur. Microbiol. Soc.) Microbiol. Lett. 203:165-171.

Davis, M. J., French, W. J., and Schaad, N. W. 1981. Axenic culture of the bacteria associated with phony peach disease of peach and plum leaf scald. Curr. Microbiol. 6:309-314.

Davis, M. J., Purcell, A. H., and Thomson, S. V. 1980. Isolation medium for the Pierce's disease bacterium. Phytopathology 70:425-429.

De Lima, J. E. O., Miranda, V. S., Hartung, J. S., Brlansky, R. H., Coutinho, A., Roberto, S. R., and Carlos, E. F. 1998. Coffee leaf scorch bacterium: Axenic culture, pathogenicity, and comparison with Xylella fastidiosa of citrus. Plant Dis. 82:94-97.

DeLoney, C. R., Bartley, T. M., and Visick, K. L. 2002. Role for phosphoglucomutase in Vibrio fischeri-Euprymna scolopes symbiosis. J. Bacteriol. 184:5121-5129.

de Souza, A. A., Takita, M. A., Coletta-Filho, H. D., Caldana, C., Goldman, G. H., Yanai, G. M., Muto, N. H., de Oliveira, R. C., Nunes, L. R., and Machado, M. A. 2003. Analysis of gene expression in two growth states of Xylella fastidiosa and its relationship with pathogenicity. Mol. PlantMicrobe Interact. 16:867-875.

de Souza, A. A., Takita, M. A., Coletta-Filho, H. D., Caldana, C., Yanai, G. M., Muto, N. H., de Oliveira, R. C., Nunes, L. R., and Machado, M. A. 2004. Gene expression profile of the plant pathogen Xylella fastidiosa during biofilm formation in vitro. FEMS (Fed. Eur. Microbiol. Soc.) Microbiol. Lett. 237:341-353.

Dow, J. M., Clarke, B. R., Milligan, D. E., Tang, J. L., and Daniels, M. J. 1990. Extracellular proteases from Xanthomonas campestris pv. campestris, the black rot pathogen. Appl. Environ. Microbiol. 56:29942998

Dow, J. M., Newman, A.-A., and von Roepenack, E. 2000. The induction and modulation of plant defense responses by bacterial lipopolysaccharides. Annu. Rev. Phytopathol. 38:241-261.

Dow, J. M., Osbourn, A. E., Wilson, T. J. G., and Daniels, M. J. 1995. A locus determining pathogenicity of Xanthomonas campestris is involved in lipopolysaccharide biosynthesis. Mol. Plant-Microbe Interact. 8:768777.

Erbs, G., and Newman, M.-A. 2003. The role of lipopolysaccharides in induction of plant defense. Mol. Plant Pathol. 4:421-425. 
Espinoas-Urgel, M., Salido, A., and Ramos, J. L. 2000. Genetic analysis of functions involved in adhesion of Pseudomonas putida to seeds. J. Bacteriol. 182:2363-2369.

Feil, H., Feil, W. S., Detter, J. C., Purcell, A. H., and Lindow, S. E. 2003. Site-directed disruption of the fim A and fimB fimbrial genes of Xylella fastidiosa. Phytopathology 93:675-682.

Foreman-Wykert, A. K., and Miller, J. F. 2003. Hypervirulence and pathogen fitness. Trends Microbiol. 11:105-108.

Fry, S. M., and Milholland, R. D. 1990. Response of resistant, tolerant and susceptible grapevine tissues to invasion by the Pierce's disease bacterium Xylella fastidiosa. Phytopathology 80:66-69.

Fry, S. M., Huang, J-S., and Milholland, R. D. 1994. Isolation and preliminary characterization of extracellular proteases produce by strains of Xylella fastidiosa from grapevines. Phytopathology 84:357-363.

Guedin, S., Willery, E., Tommassen, J., Fort, E., Drobecq, H., Locht, C., and Jacob-Dubuisson, F. 2000. Novel topological features of FhaC, the outer membrane transporter involved in the secretion of the Bordetella pertussis filamentous hemagglutinin. J. Biol. Chem. 275:30202-30210.

Guilhabert, M. R., Hoffman, L. M., Mills, D. A., and Kirkpatrick, B. C 2001. Transposon mutagenesis of Xylella fastidiosa by electroporation of Tn5 synaptic complexes. Mol. Plant-Microbe Interact. 14:701-706.

Guilhabert, M. R., and Kirkpatrick., B. C. 2003. Transformation of Xylella fastidiosa with broad host range RSF1010 plasmids. Mol. Plant Pathol. 4:279-285.

Hatterman, D. R., and S. M. Ries. 1989. Motility of Pseudomonas syringae pv. glycinea and its role in infection. Phytopathology 79:284-289.

Hawes, M. C., and L. Y. Smith. 1989. Requirement for chemotaxis in pathogenicity of Agrobacterium tumefaciens on roots of soil-grown pea plants. J. Bacteriol. 171:5668-5671.

Hearon, S. S., Sherald, J. L., and Kostka, S. J. 1980. Association of xylemlimited bacteria with elm, sycamore, and oak leaf scorch. Can. J. Bot. 58:1986-1993.

Henderson, I., Nataro, J. P., Kaper, J. B., Meyer, T. F., Farrand, S. K., Burns D. L., Finlay, B. B., and St Geme, J. W., III. 2000. Renaming protein secretion in gram-negative bacteria. Trends Microbiol. 8:352.

Hermann, S. R., Miller, J. A., O’Neill, S., Tsao, T. T., Harding, R. M., and Dale, J. L. 2000. Single-primer amplification of flanking sequences. Biotechniques 29:1176-1178, 1180.

Hill, B. L., and Purcell, A. H. 1995. Multiplication and movement of Xylella fastidiosa within grapevine and four other plants. Phytopathology 85:1368-1372.

Hopkins, D. L. 1985. Physiological and pathological characteristics of virulent and avirulent strains of the bacterium that causes Pierce's disease of grapevine. Phytopathology 75:713-717.

Hopkins, D. L. 1989. Xylem-limited bacterial pathogen of plants. Annu. Rev. Phytopathol. 27:271-290.

Hopkins, D. L., Mollenhauer, H. H., and Mortensen, H. H. 1974. Tolerance to Pierce's disease and the associated rickettsia-like bacterium in muscadine grape. J. Am. Soc. Hortic. Sci. 99:436-439.

Inzana, T. J., and Apicella, M. A. 1999. Use of a bilayer stacking gel to improve resolution of lipopolysaccharides and lipooligosaccharides in polyacrylamide gels. Electrophoresis 20:462-465.

Jacob-Dubuisson, F., El-Hamel, C., Saint, N., Guedin, S., Willery, E., Molle, G., and Locht, C. 1999. Channel formation by FhaC, the outer membrane protein involved in the secretion of the Bordetella pretussis filamentous hemagglutinin. J. Biol. Chem. 274:37731-37735.

Jacob-Dubuisson, F., Locht, C., and Antoine, R. 2001. Two-partner secretion in gram-negative bacteria: A thrifty, specific pathway for large virulence proteins. Mol. Microbiol. 40:306-313.

Kang Y., Liu, H., Genin, S., Schell, M. A., and Denny, T. P. 2002. Ralstonia solanacearum requires type 4 pili to adhere to multiple surfaces and for natural transformation and virulence. Mol. Microbiol. 46:427-437.

Kannenberg, E. L., Perotto, S., Bianciotto, V., Rathbun, E. A., and Brewin, N. J. 1994. Lipopolysaccharide epitope expression of Rhizobium bacteroids as revealed by in situ immunolabeling of pea root nodule sections. J. Bacteriol. 176:2021-2032.

Kingsley, M. T., Gabriel, D. W., Marlow, G. C., and Roberts, P. D. 1993. The ops X locus of Xanthomonas campestris affects host range and biosynthesis of lipopolysaccharide and extracellular polysaccharide. J. Bacteriol. 175:5839-5850.

Koide, T., Zaini, P. A., Moreira, L. M., Vencio, R. Z., Matsukuma, A. Y., Durham, A. M., Teixeira, D. C., El-Dorry, H., Monteiro, P. B., da Silva, A. C., Verjovski-Almeida, S., da Silva, A. M., and Gomes, S. L. 2004. DNA microarray-based genome comparison of a pathogenic and a nonpathogenic strain of Xylella fastidiosa delineates genes important for bacterial virulence. J. Bacteriol. 186:5442-5449.

Konninger, U. W., Hobbie, S., Benz, R., and Braun, V. 1999. The haemolysin-secreting ShlB protein of the outer membrane of Serratia marcescens: Determination of surface-exposed residues and formation of ionpermeable pores by ShlB mutants in artificial lipid bilayer membranes.
Mol. Microbiol. 32:1212-1225.

Kwakman, J. H., and Postma, P. W. 1994. Glucose kinase has a regulatory role in carbon catabolite repression in Streptomyces coelicolor. J. Bacteriol. 176:694-698.

Leite, B., Andersen, P. C., and Ishida, M. L. 2004. Colony aggregation and biofilm formation in xylem chemistry-based media for Xylella fastidiosa. FEMS (Fed. Eur. Microbiol. Soc.) Microbiol. Lett. 230:283290.

Li, W.-B., Zhou, C.-H., Pria, W. D., Teixeira, D. C., Miranda, V. S. Pereira, E. O., Ayres, A. J., He, C.-X., Costa, P. I., and Hartung, J. S. 2002. Citrus and coffee strains of Xylella fastidiosa induce Pierce's disease in grapevines. Plant Dis. 86:1206-1211.

Locht, C., Antoine, R., and Jacob-Dubuisson, F. 2001. Bordetella pertussis, molecular pathogenesis under multiple aspects. Curr. Opin. Microbiol. 4:82-89.

Lyon, W. R., and Caparon, M. G. 2004. Role for serine protease HtrA (DegP) of Streptococcus pyogenes in the biogenesis of virulence factors SpeB and the hemolysin streptolysin S. Infect. Immun. 72:1618-1625.

Madigan, M. T., Martinko, J. M., and Parker, J. 1970. Brock Biology of Microorganisms. Prentice Hall, Upper Saddle River, NJ.

Marques, L. L. R., Ceri, H., Manfio, G. P., Reid, D. M., and Olson, M. E. 2002. Characterization of biofilm formation by Xylella fastidiosa in vitro. Plant Dis. 86:633-638.

Matthysse, A. G., and McMahan, S. 1998. Root colonization by Agrobacterium tumefaciens is reduced in cel, att $\mathrm{B}$, att $\mathrm{D}$, and att $\mathrm{R}$ mutants. Appl. Environ. Microbiol. 64:2341-2345.

McCoy, R. E. 1982. Chronic and insidious disease: The fastidious vascular pathogens. Pages 475-489 in: Phytopathogenic Procaryotes. M. S. Mount and G. H. Lacy, eds. Academic Press, New York.

Mollenhauer, H., H., and Hopkins, D., L. 1974. Ultrastructural study of Pierce's disease bacterium in grape xylem tissue. J. Bacteriol. 119:612618.

Mouslim, C., Hilbert, F., Huang, H., and Groisman, E. A. 2002. Conflicting needs for a Salmonella hypervirulence gene in host and non-host environments. Mol. Microbiol. 45:1019-1027.

Newman, K. L., Almeida, R. P. P., Purcell, A. H., and Lindow, E. S. 2003. Use of a green fluorescent strain for analysis of Xylella fastidiosa colonization of Vitis vinifera. Appl. Environ. Microbiol. 69:7319-7327.

Newman, K. L., Almeida, R. P. P., Purcell, A. H., and Lindow, E. S. 2004. Cell-cell signaling controls Xylella fastidiosa interactions with both insects and plants. Proc. Natl. Acad. Sci. U.S.A. 101:1737-1742

Newman, M. A., von Roepenack-Lahaye, E., Parr, A., Daniels, M. J., and Dow, J. M. 2002. Prior exposure to lipopolysaccharide potentiates expression of plant defenses in response to bacteria. Plant J. 29:487-495.

Ojanen-Reuhs, T., Kalkkinen, N., Westerlund-Wikstrom, B., van Doorn, J., Haahtela, K., Nurmiaho-Lassila, E. L., Wengelnik, K., Bonas, U., and Korhonen, T. K. 1997. Characterization of the fimA gene encoding bundle-forming fimbriae of the plant pathogen Xanthomonas campestris pv. vesicatoria. J. Bacteriol. 179:1280-1290.

Ottemann, K. M., and J. F. Miller. 1997. Roles for motility in bacterialhost interactions. Mol. Microbiol. 24:1109-1117.

Panapoulos, N. J., and M. N. Schroth. 1974. Role of flagellar motility in the invasion of bean leaves by Pseudomonas phaseolicola. Phytopathology 64:1389-1397.

Park, J. Y., Takahara, N., Gabriele, A., Chou, E., Naruse, K., Suzuma, K. Yamauchi, T., Ha, S. W., Meier, M., Rhodes, C. J., and King, G. L. 2000. Induction of endothelin-1 expression by glucose: An effect of protein kinase C activation. Diabetes 49:1239-1248.

Pennings, J. L., Keltjens, J. T., and Vogels, G. D. 1998. Isolation and characterization of Methanobacterium thermoautotrophicum DeltaH mutants unable to grow under hydrogen-deprived conditions. J. Bacteriol. 180:2676-2681.

Purcell, A. H. 1997. Xylella fastidiosa, a regional problem or global threat? J. Plant. Pathol. 79:99-105.

Purcell, A., H., and Hopkins, D., L. 1996. Fastidious xylem-limited bacterial plant pathogens. Annu. Rev. Phytopathol. 34:131-151.

Purcell, A. H., and Saunders, S. R. 1999. Fate of Pierce's disease strains of Xylella fastidiosa in common riparian plants in California. Plant Dis. 83:825-830.

Qin, X., and Hartung, J. S. 2001. Construction of a shuttle vector and transformation of Xylella fastidiosa with plasmid DNA. Curr. Microbiol. 43:158-162.

Ray, S. K., Rajeshwari, R., Sharma, Y., and Sonti, R. V. 2002. A high-molecular-weight outer membrane protein of Xanthomonas oryzae pv. oryzae exhibits similarity to non-fimbrial adhesins of animal pathogenic bacteria and is required for optimum virulence. Mol. Microbiol. 46:637-647.

Rojas, C. M., Ham, J. H., Deng, W.-L., and Doyle, J. J. 2002. HecA, member of a class of adhesins produced by diverse pathogenic bacteria, contributes to the attachment, aggregation, epidermal cell killing, and 
virulence phenotypes of Erwinia chrysanthemi EC16 on Nicotiana clevelandii seedlings. Proc. Natl. Acad. Sci. U.S.A. 99:13142-13147.

Romantschuk, M., and Bamford, D. H. 1986. The causal agent of halo blight in bean, Pseudomonas syringae pv. phaseolicola, attaches to stomata via its pili. Microb. Pathog. 1:139-148.

Roper, M. C., Greve, L. C., Labavitch, J., and Kirkpatrick, B. 2002. Analysis of grapevine xylem sap for evidence of host cell wall degrading enzymes associated with colonization by Xylella fastidiosa. (Abstr.) Phytopathology 92:S70.

Roper, M. C., Greve, L. C., Stevenson, J., Labavitch, J., and Kirkpatrick, B. 2003. Biochemical evidence of bacterial exopolysaccharide production in grapevines infected with Xylella fastidiosa, the causal agent of Pierce's disease. (Abstr.) Phytopathology 93:S74.

Schaible, U. E., and Kaufmann, S. H. 2004. Iron and microbial infection. Nat. Rev. Microbiol. 2:946-953.

Schönherr, R., Tsolis, R., Focareta, T., and Braun, V. 1993. Amino acid replacements in the Serratia marcescens haemolysin ShIA define sites involved in activation and secretion. Mol. Microbiol. 9:1229-1237.

Simpson, A. J. G., Reinach, F. C., Arruda, P., Areu. F. A., Acencio, M., et al. 2000. The genome sequence of the plant pathogen Xylella fastidiosa. Nature 406:151-157.

Skurnik, M., and Toivanen, P. 1993. Yersinia enterocolitica lipopolysaccharide: Genetics and virulence. Trends Microbiol. 1:148-152.

Smart C. D., Schneider, B., Blomquist, C. L., Guerra, L. J., Harrison, N. A., Ahrens, U., Lorenz, K. H., Seemuller, E., and Kirkpatrick., B. C. 1996. Phytoplasma-specific PCR primers based on sequences of the 16S-23S rRNA spacer region. Appl. Environ. Microbiol. 62:2988-2993.

Sohel, I., Puente, J. L., Murray, W. J., Vuopio-Varkila. J., and Schoolnik, G. K. 1993. Cloning and characterization of the bundle-forming pilin gene of enteropathogenic Escherichia coli and its distribution in Salmonella serotypes. Mol. Microbiol. 7:563-575.

Spath, C., Kraus, A., and Hillen, W. 1997. Contribution of glucose kinase to glucose repression of xylose utilization in Bacillus magaterium. J. Bacteriol. 179:7603-7605.

Stevenson, J. F., Matthews, M. A., Greve, L. C., Labavitch, J. M., and Rost, T. L. 2004. Grapevine susceptibility to Pierce's Disease II: Progression of anatomical symptoms. A. J. Enol. Vitic. 53:238-243.
Strom, M. S., and Lory, S. 1993. Structure-function and biogenesis of the type IV pili. Annu. Rev. Microbiol. 47:565-596.

Tans-Kersten, J., Huang, H., and Allen, C. 2001. Ralstonia solanacearum needs motility for invasive virulence on tomato. J. Bacteriol. 183:35973605 .

Thompson, J. D., Higgins, D. G., and Gibson, T. J. 1994. CLUSTAL W: Improving the sensitivity of progressive multiple sequence alignment through sequence weighting, position-specific gap penalties and weight matrix choice. Nucleic Acids Res. 22:4673-4680.

Tsai, C. M., and Frasch, C. E. 1982. A sensitive silver stain for detecting lipopolysaccharides in polyacrylamide gels. Anal. Biochem. 119:115-119.

VandeBroek, A., and Vanderleyden, J. 1995. The role of bacterial motility, chemotaxis, and attachment in bacteria-plant interactions. Mol. PlantMicrobe Interact. 8:800-810.

van Doorn, J., Boonekamp, P. M., and Oudega, B. 1994. Partial characterization of fimbriae of Xanthomonas campestris pv. hyacinthi. Mol. Plant-Microbe Interact. 7:334-344.

Van Sluys, M. A., de Oliveira, M. C., Monwieo-Vitorello, C. B., Miyaki, C. Y., Furlan, L. R., et al. 2003. Comparative analyses of the complete genome sequences of Pierce's disease and citrus variegated chlorosis strains of Xylella fastidiosa. J. Bacteriol. 185:1018-1026.

Wagner, E., Marcandier, S., Egeter, O., Deutscher, J., Gotz, F., and Bruckner, R. 1995. Glucose kinase-dependent catabolite repression in Staphylococcus xylosus. J. Bacteriol. 177:6144-6152.

Zhang, Y. P., Uyemoto, J. K., and Kirkpatrick, B. C. 1998. Small-scale procedure for extracting nucleic acids from woody plants infected with various phytopathogens for PCR assay. J. Virol. Methods 71:45-50.

\section{AUTHOR RECOMMENDED INTERNET RESOURCES}

Laboratory for Bioinformatics, University of Campinas (UNICAMP) $X$. fastidiosa PD genome web site: www.lbi.ic.unicamp.br/

UNICAMP Xylella fastidiosa-Pierce's disease strain genome sequence website aeg.lbi.ic.unicamp.br/world/xfpd/

University of California Alexander Purcell Laboratory's Pierce's disease database: www.cnr.berkeley.edu./xylella/index.html 